\title{
SYNTHESIS AND COORDINATION CHEMISTRY OF THIOPHENOL-BASED HETERODONOR LIGANDS CONTAINING P,S, As,S AND P,SAs DONOR ATOMS
}

\author{
Imola Sárosi ${ }^{1}$, Luminiţa Silaghi-Dumitrescu², Evamarie Hey-Hawkins ${ }^{1 *}$ \\ ${ }^{1}$ Universität Leipzig, Institut für Anorganische Chemie, \\ Johannisallee 29, D-04103 Leipzig, Germany \\ ${ }^{2}$ Faculty of Chemistry and Chemical Engineering, Babeş-Bolyai University, \\ Kogalniceanu 1, RO-400084 Cluj-Napoca, Romania \\ hey@uni-leipzig.de
}

\begin{abstract}
This review article describes the synthesis and coordination chemistry of three types of thiophenolbased heterodonor ligands containing tertiary phosphine and/or arsine groups in combination with sulfur. Phenylthio(diphenyl)phosphine and -arsine ligands, $\mathrm{EPh}_{2}(\mathrm{SPh})(\mathrm{E}=\mathrm{P}, \mathrm{As})$, incorporate an $\mathrm{E}-\mathrm{S}$ bond in their structures. Upon reaction with different metal carbonyls, metal-mediated cleavage of the E-S bonds of these ligands has been observed, leading to a variety of sulfur- and phosphorus- or arsenic-containing metallacycles. The structurally isomeric phosphino- and arsinoarylthiols $\mathrm{HSC}_{6} \mathrm{H}_{4}-2-\mathrm{EPh}_{2}(\mathbf{E S H})$ combine a phosphine or arsine centre with a thiol functionality, which is usually deprotonated on coordination. These compounds have been shown to be very versatile ligands that form stable complexes with a wide range of transition metals. The heterotopic ligand 1- $\mathrm{Ph}_{2} \mathrm{AsSC}_{6} \mathrm{H}_{4}-2-\mathrm{PPh}_{2}$ (P,SAs) not only combines the properties of phenylthio(diphenyl) arsine and 2-diphenylphosphanylbenzenethiol by incorporating all three donor atoms in its structure, but also allows the effect of the $\mathrm{PPh}_{2}$ group in the ortho position on the cleavage of the As-S bond to be studied.
\end{abstract}

Keywords: P,S ligands; As,S ligands; P,SAs ligands; synthetic methods; transition metal complexes

\section{СИНТЕЗА И КООРДИНАЦИОНА ХЕМИЈА НА ТИОФЕНОЛНИ ХЕТЕРОДОНОРНИ ЛИГАНДИ СО P,S, As,S И P,SAs ДОНОРНИ АТОМИ}

Во овој преглед е опишана синтезата и координационата хемија на три типа тиофенолни хетеродонорни лиганди што содржат терцијарни фосфински и/или арсински групи во комбинација со сулфур. Фенилтио(дифенил)фосфинските и арсинските лиганди од типот $\mathrm{EPh}_{2}(\mathrm{SPh})(\mathrm{E}=\mathrm{P}$, As) во своите структури ја содржат врската E-S. При реакција со различни метални карбонили се забележува раскинување на врската E-S со помош на металот, при што се добиваат разновидни сулфурни и фосфорни или арсенови метал-ациклични соединенија. Структурно изомерните фосфинои арсиноарилтиоли $\mathrm{HSC}_{6} \mathrm{H}_{4}-2-\mathrm{EPh}_{2}$ (ESH) градат фосфински или арсински центри со особини на тиолна група која обично при координација се депротонира. Овие соединенија се покажаа како многу сестрани лиганди кои градат стабилни комплекси со разновидни преодни метали. Хетеротропните лиганди 1- $\mathrm{Ph}_{2} \mathrm{AsSC}_{6} \mathrm{H}_{4}-2-\mathrm{PPh}_{2}$ (P,SAs), со трите донорни атоми во својата структура, не само што ги комбинираат својствата на фенилтио(дифенил)арсините и на 2-дифенилфосфанилбензентиолите, туку овозможуваат и испитување на влијанието на групата $\mathrm{PPh}_{2}$ во ортоположбата при раскинувањето на врската As-S.

Клучни зборови: P,S лиганди; As,S лиганди; P,SAs лиганди; методи за синтеза; комплекси на преодни метали. 


\section{INTRODUCTION}

\section{Hemilabile ligands}

Ligands which contain significantly different chemical functions, such as hard and soft donor atoms or groups (often called hybrid ligands, Scheme 1A) find increasing use in molecular chemistry because of the selectivity introduced in the metal-ligand interactions and their possible dynamic behaviour [1] Hemilabile ligands have been the topic of excellent review articles in the last years [1-5], and their potential use in catalysis has also been reviewed [6-8].

The term "hemilabile ligand" was introduced more than 30 years ago by Jeffrey and Rauchfuss [9], although the phenomenon itself had been observed earlier [10, 11]. Hybrid ligands (polydentate ligands) contain at least two different types of functional groups capable of binding to metal centres. The different nature of these chemical functionalities often leads to enhanced diversity concerning their resulting interaction with metal centres, thus leading to chemoselectivity (Scheme 1B) [12].

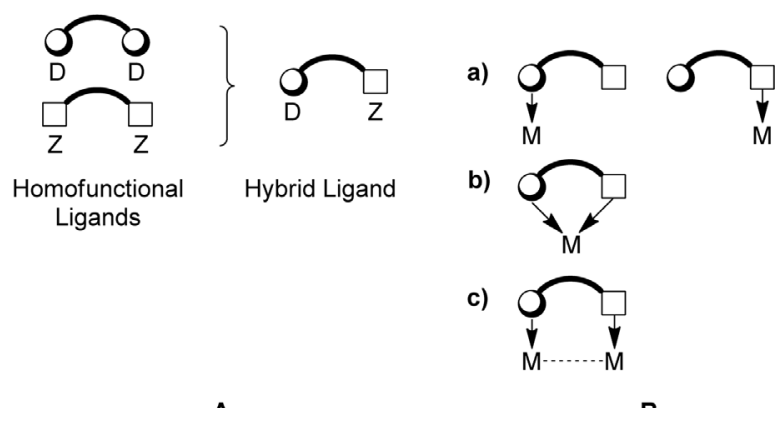

Scheme 1

A) Hybrid ligands contain at least two chemically different donor functions.

B) Bonding modes of hybrid ligands:

(a) monodentate; (b) chelating (with chemically different metal-ligand interactions); (c) bridging (with or without the presence of metal-metal bonding) [1]

Hemilabile ligands were first investigated in mononuclear metal complexes, but the concept of hemilability can easily be extended to dinuclear complexes [13] and metal clusters $[14,15]$. In principle, a ligand containing one strongly binding and one weakly binding donor can be used to stabilise an active metal centre. Metal-heteroatom bonds of different strength can cause ring-opening in the metal complex by rupture of the weakest coordinative bond. The recoordination of the free donor group then leads to a reversible process [3].

\section{$P, S$ and As,S mixed-donor ligands}

The search for new and more efficient catalytically active transition metal complexes is based on the design and synthesis of appropriate ligands. There is considerable current interest in heterodonor polydentate ligands involving tertiary phosphine and arsine groups in combination with sulfur donors. While phosphorus-based ligands have been widely explored [16-29], the combination of arsenic and one or more sulfur-donor atoms in the same ligand is not widely exploited. Probably one reason for the lack of development in this field is the fact that ${ }^{75} \mathrm{As}$ (spin 3/2) is not a readily accessible NMR nucleus. In contrast, the ${ }^{31} \mathrm{P}$ nucleus ( spin $1 / 2$ ) is easily detected, shows about three times the receptivity of ${ }^{75} \mathrm{As}$, and no quadrupole moment [30]. Even though negligible work has been carried out on systems containing tertiary arsine donor groups compared to their phosphorus analogues, arsenic has many advantages over phosphorus when it comes to the synthesis of organic derivatives. For example, for arsines of the type $A s R^{1} R^{2} R^{3}$ these include reduced air sensitivity, increased conformational stability and easier recovery from arsonium salts and metal complexes [31]. There are examples of transitionmetal complexes of triorganoarsines that are at least as good or even more efficient catalysts in organic synthesis than the phosphorus-containing analogues in Stille [32, 33] and Suzuki-Miyaura coupling reactions $[34,35]$, hydroformylation of terminal alkenes [36], Heck olefination [37], carbonylation [38] and asymmetric Wittig olefination [39]. 
Tertiary phosphine and arsine ligands derived from thiophenol have been shown to be very versatile ligands that form stable complexes with a wide range of transition metals. The low ionisation energy of sulfur and the presence of several lone pairs of electrons (three in the case of a thiolate anion) offer the possibility of a rich sulfur-based chemistry of the complexes [5]. Metal thiolates can form complexes with various nuclearities and great structural complexity as a result of the tendency of the thiolate ligands to bridge metal centres [40-43].

Further on, the literature overview will focus on three major groups of thiophenol-based heterotopic E,S ligands ( $\mathrm{E}=\mathrm{As}, \mathrm{P})$ :

1. phenylthio(diphenyl)phosphine and -arsine ligands: $\mathrm{EPh}_{2}(\mathrm{SPh})$,

2. bidentate phosphanyl- and arsanylarylthiol ligands: $\mathrm{HSC}_{6} \mathrm{H}_{4}-2-\mathrm{EPh}_{2}$ (ESH),

3. a heterotopic ligand which combines the properties of phenylthio(diphenyl)arsine and 2-diphenylphosphanylbenzenethiol, namely, 1- $\mathrm{Ph}_{2} \mathrm{AsSC}_{6} \mathrm{H}_{4}-2-\mathrm{PPh}_{2}$ (P,SAs)

The next three chapters describe the synthesis and coordination chemistry of these ligands with transition metal complexes; the metal-mediated cleavage of the $\mathrm{E}-\mathrm{S}$ bond in the $\mathrm{EPh}_{2}(\mathrm{SPh})$ and P,SAs ligands, respectively the coordination of the mixed-donor E,S chelating groups of the bidentate ligands $\mathbf{E S H}$ is being investigated.

\section{SYNTHESIS AND COORDINATION CHEMISTRY OF THE LIGANDS EPh ${ }_{2}(\mathrm{SPh})$}

\subsection{Preparation of $E P h_{2}(S P h)$}

Phenylthio(diphenyl)phosphine was isolated in 1963 from the reaction of diphenylphenylcarbamoyl-phosphine with diphenyl disulfide [44], while phenylthio(diphenyl)arsine was reported in the same year as the reaction product of benzenethiolate, sodium metal and diphenylchloroarsine [45]. Scheme 2 shows the discussed compounds.

Since then, alternative synthesis routes to prepare these compounds have been published. B. E. Job et al. proposed the treatment of sodium thiophenolate with a solution of diphenylchlorophosphine in diethyl ether under dry nitrogen in order to prepare the $\mathrm{PPh}_{2}(\mathrm{SPh})$ ligand [46]. During the last 40 years, different synthetic routes of phenylthio(diphenyl)phosphine were the topic of further numerous articles [47-52].

In their study regarding the air oxidation of some arsenic(III) compounds, T. D. Sideris and P. V. Ioannou proposed the reaction of tetraphenyldiarsine oxide and thiophenol in methanol for the preparation of $\mathrm{AsPh}_{2}(\mathrm{SPh})$ [53].

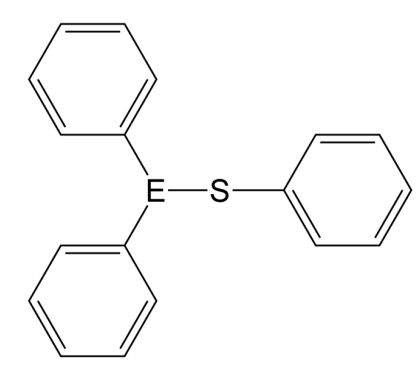

Scheme 2. Thioarsine and thiophosphine ligands: $\mathrm{EPh}_{2}(\mathrm{SPh})(\mathbf{E}-\mathrm{S}, \mathrm{E}=\mathrm{As}, \mathrm{P})$

\subsection{Coordination chemistry of $E P h_{2}(S P h)$}

The metal-mediated cleavage of the $\mathrm{P}-\mathrm{S}$ and As-S bonds of these ligands has been observed in their reactions with different metal carbonyls. These reactions usually led to a variety of metallacyclic products containing sulfur and phosphorus or arsenic within the ring. Even though the metal-mediated breaking of As-S bonds in inorganic molecules such as $\mathrm{As}_{4} \mathrm{~S}_{4}$ has received considerable attention [54-62], the cleavage of As-S bonds in thioarsines remains relatively unexplored. Compared to the rich coordination chemistry of $\mathrm{PPh}_{2}(\mathrm{SPh})$, only a few reactions of $\mathrm{AsPh}_{2}(\mathrm{SPh})$ with some metal carbonyl complexes are reported. 


\section{Iron complexes}

The first reported complex of $\mathrm{PPh}_{2}(\mathrm{SPh})$ is a dinuclear iron compound. At the same time it is the first example of a dinuclear metal carbonyl complex in which the metal atoms are linked by sulfur and phosphorus atoms having hydrocarbon substituents [46]. The molecular structure of this compound was reported much later by G. Le Borgne et al. (Scheme 3). It consists of two $\mathrm{Fe}(\mathrm{CO})_{3}$ groups linked by one iron-iron bond bridged through two different ligands, one sulfur and one phosphorus atom, showing a butterfly shape, which results from the junction of the basal planes of two distorted tetragonal pyramids along the edge. These pyramids are formed by the five atoms coordinated to each iron atom, namely, the three carbon atoms of carbonyl groups and the bridging $\mathrm{S}$ and $\mathrm{P}$ atoms [63].

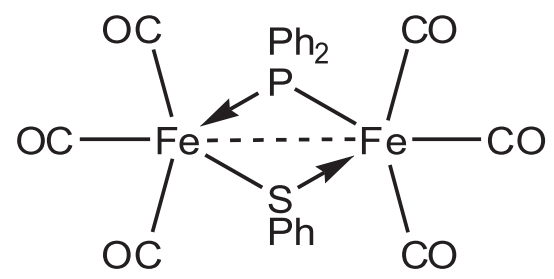

Scheme 3. Schematic drawing of $\left[\mathrm{Fe}_{2}(\mathrm{CO})_{6}\left(\mu-\mathrm{PPh}_{2}\right)(\mu-\mathrm{SPh})\right]$
The thermolysis of $\mathrm{AsPh}_{2}(\mathrm{SPh})$ and $\left[\mathrm{FeCp}(\mathrm{CO})_{2}\right]_{2}$ led to formation of $\left[\mathrm{Fe}_{2} \mathrm{Cp}_{2}(\mathrm{CO})_{2}\right.$ $\left.\left(\mu-\mathrm{AsPh}_{2}\right)(\mu-\mathrm{SPh})\right]($ Scheme 4$)$. The two iron atoms are bridged by an $\mathrm{AsPh}_{2}$ ligand and by an $\mathrm{SPh}$ ligand. In addition, each iron atom is ligated by one carbonyl group and a cyclopentadienyl ligand. The two metal centres are held together by virtue of the bridging ligands only [64].

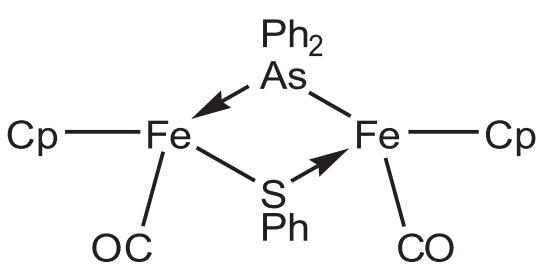

Scheme 4. Schematic drawing of $\left[\mathrm{Fe}_{2} \mathrm{Cp}_{2}(\mathrm{CO})_{2}\left(\mu-\mathrm{AsPh}_{2}\right)(\mu-\mathrm{SPh})\right]\left(\mathrm{Cp}=\mathrm{C}_{5} \mathrm{H}_{5}\right)$

In an attempt to prepare 1-(diphenylphosphino)-1'-(phenylthio)ferrocene by treating $\left(\mathrm{C}_{5} \mathrm{H}_{4} \mathrm{Li}\right)_{2} \mathrm{Fe}$ with $\mathrm{PPh}_{2}(\mathrm{SPh})$, instead of the desired compound, 1,1'-bis(diphenylphosphino) ferrocene was obtained as the main product. This result shows that nucleophilic cleavage of the $\mathrm{P}-\mathrm{S}$ bond leaves $\mathrm{PPh}_{2}$ rather than $\mathrm{SPh}$ attached to the $\mathrm{Cp}$ ring, and consequently both $\mathrm{Cp}$ rings become functionalized by $\mathrm{P}$ donor atoms (Scheme 5) [65].
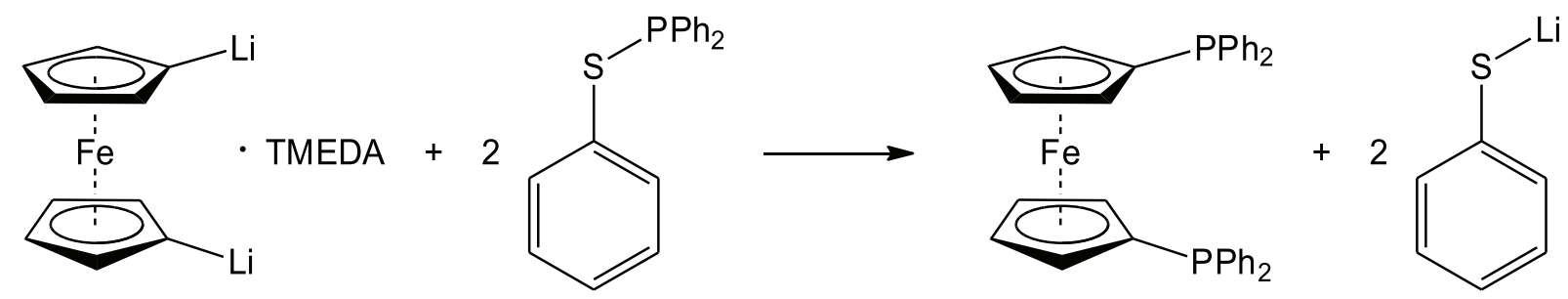

Scheme 5. Synthetic route of

1,1'-bis(diphenylphosphino)ferrocene 


\section{Cobalt complexes}

$\left[\mathrm{Co}_{2}(\mathrm{CO})_{4}\{\mu-\mathrm{S}(\mathrm{Ph}) \mathrm{C}(\mathrm{O}) \mathrm{CHCH})-\kappa S, C-\right.$ $\left.\kappa C\}\left(\mu-\mathrm{PPh}_{2}\right)\right]$ (Scheme 6) was reported as the reaction product of $\mathrm{PPh}_{2}(\mathrm{SPh})$ with $\left[\mathrm{Co}_{2}(\mathrm{CO})_{6}-\right.$ $(\mu-\mathrm{HCCH})]$. The X-ray structure determination shows that the $\mathrm{SPh}$ group has been incorporated into the five-membered metallacyclic ring and that the two Co atoms are bridged by the new $\mathrm{PhSC}(\mathrm{O}) \mathrm{CHCH}^{-}$ligand [66]. Treatment with ${ }^{13} \mathrm{CO}$ and monitoring of the reaction by ${ }^{13} \mathrm{C}\left\{{ }^{1} \mathrm{H}\right\}$ NMR spectroscopy revealed that the reaction proceeds by initial coordination of the intact $\mathrm{PPh}_{2}(\mathrm{SPh})$ ligand, followed by phosphorussulfur bond cleavage and subsequent coupling of the thiolate fragment with a coordinated $\mathrm{CO}$ and $\mathrm{CHCH}$ group on the dicobalt complex [67].

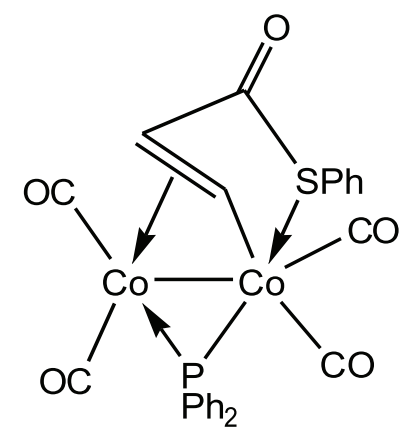

Scheme 6. Schematic drawing of $\left.\left[\mathrm{Co}_{2}(\mathrm{CO})_{4}\{\mu-\mathrm{S}(\mathrm{Ph}) \mathrm{C}(\mathrm{O}) \mathrm{CHCH})-\kappa S, C-\kappa C\right\}\left(\mu-\mathrm{PPh}_{2}\right)\right]$
Dicobalt octacarbonyl reacts in a complex manner with $\mathrm{PPh}_{2}(\mathrm{SPh})$. Depending on the reaction conditions employed a combination of products with a $\mathrm{Co}_{3} \mathrm{~S}$ tetrahedrane core can be observed, in which a $\mathrm{PPh}_{2}$ group bridges one of the Co-Co edges. In dichloromethane solution at room temperature the trimetallic species $\left[\mathrm{Co}_{3}\left(\mu_{3}-\mathrm{S}\right)\left(\mu-\mathrm{PPh}_{2}\right)(\mathrm{CO})_{7}\right]$ and $\left[\mathrm{Co}_{3}\left(\mu_{3}-\mathrm{S}\right)-\right.$ $\left.\left(\mu-\mathrm{PPh}_{2}\right)(\mathrm{CO})_{6}\left(\mathrm{PPh}_{3}\right)\right]$ form, while the same reaction performed in refluxing toluene solution purged with $\mathrm{CO}$ gives the latter complex and $\left[\mathrm{Co}_{3}\left(\mu_{3}-\mathrm{S}\right)\left(\mu-\mathrm{PPh}_{2}\right)(\mathrm{CO})_{5}\left(\mathrm{PPh}_{3}\right)_{2}\right] \quad($ Scheme 7$)$ [68].

The reaction of $\left[\mathrm{Co}_{2}(\mathrm{CO})_{8}\right]$ with $\mathrm{AsPh}_{2}(\mathrm{SPh})$ afforded the complex $\left[\mathrm{Co}_{3}\left(\mu_{3}-\mathrm{S}\right)\right.$ $\left.\left(\mu-\mathrm{AsPh}_{2}\right)(\mathrm{CO})_{6}\left(\mathrm{AsPh}_{3}\right)\right]$. The adopted structure resembles that of the phosphorus-containing analogue $\left[\mathrm{Co}_{3}\left(\mu_{3}-\mathrm{S}\right)\left(\mu-\mathrm{PPh}_{2}\right)(\mathrm{CO})_{6}\left(\mathrm{PPh}_{3}\right)\right][68]$. The molecule is constructed around a distorted tetrahedral core containing three cobalt atoms and an apical sulfur atom. A diphenylarsenido group bridges $\operatorname{Co}(1)$ and $\operatorname{Co}(2)$, coordinating these atoms pseudo-equatorially. Each cobalt atom is further ligated by two carbonyl ligands, one located equatorially and the other at the axial site. The remaining equatorial position on $\mathrm{Co}(3)$ is occupied by a triphenylarsine molecule [64].

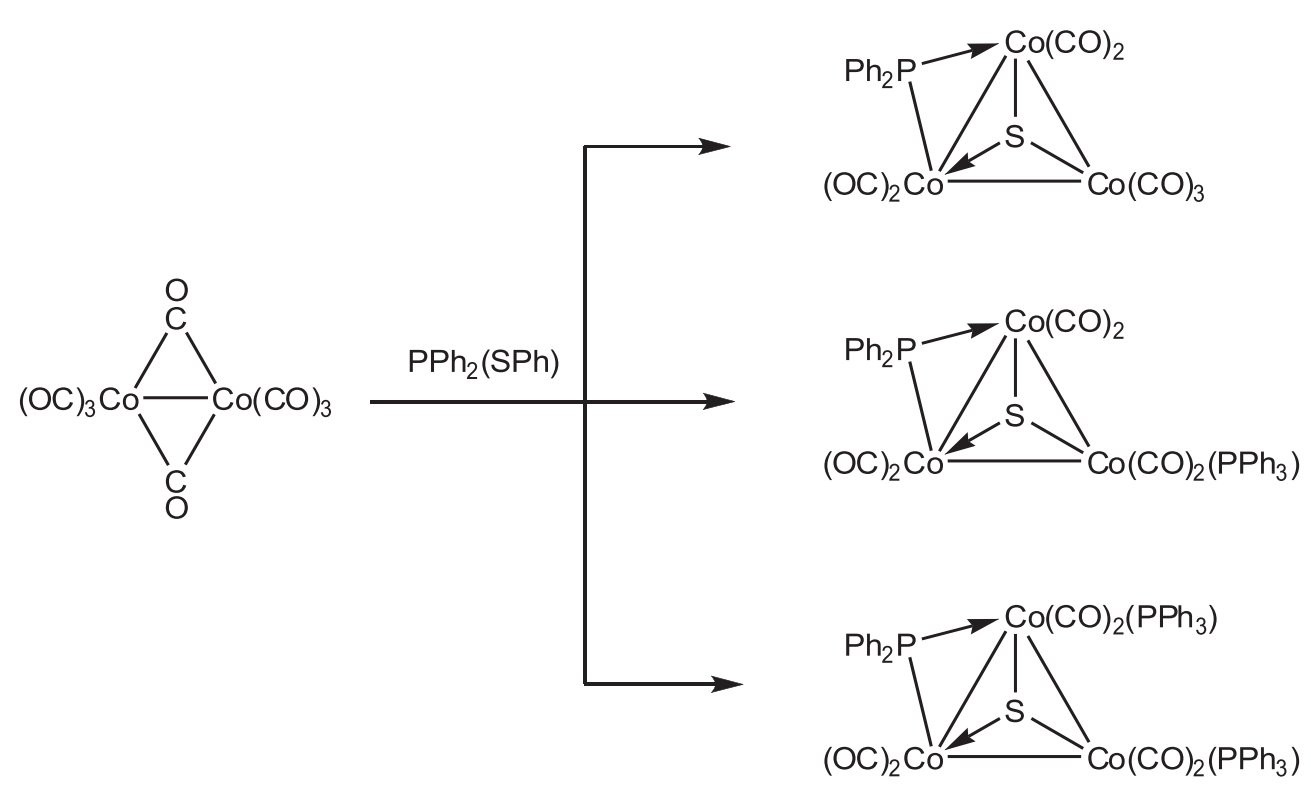

Scheme 7. Products from the reaction of dicobalt octacarbonyl with $\mathrm{PPh}_{2}(\mathrm{SPh})$ 


\section{Manganese complexes}

Reaction of $\left[\mathrm{Mn}_{2}(\mathrm{CO})_{10}\right]$ with $\mathrm{PPh}_{2}(\mathrm{SPh})$ gives the complex $\left[\mathrm{Mn}_{2}(\mathrm{CO})_{8}\left(\mu-\mathrm{PPh}_{2}\right)(\mu-\mathrm{SPh})\right]$ (Scheme 8) [68]. The arsenic analogue of this complex was reported as well [64]. The compounds have very similar butterfly structures in which the two manganese atoms are bridged by an $\mathrm{EPh}_{2}$ and a $\mathrm{SPh}$ ligand. Both atoms $\mathrm{Mn}(1)$ and $\mathrm{Mn}(2)$ are additionally ligated by four terminal $\mathrm{CO}$ groups, two equatorial and two axial, completing an approximately octahedral arrangement around each metal centre $[64,68]$.

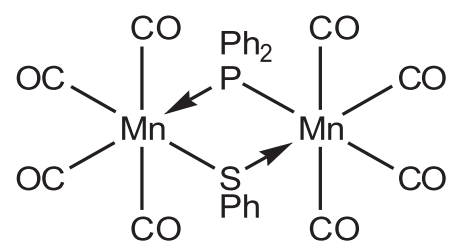
Scheme 8. Schematic drawing of
$\left[\mathrm{Mn}_{2}(\mathrm{CO})_{8}\left(\mu-\mathrm{PPh}_{2}\right)(\mu-\mathrm{SPh})\right]$

\section{Mixed-metal complexes}

Reactions of heteronuclear alkynebridged cobalt-molybdenum complexes with $\mathrm{PPh}_{2}(\mathrm{SPh})$ were studied in order to investigate the relative reactivities of the two different metal sites. In the first step, coordination of the $\mathrm{PPh}_{2}(\mathrm{SPh})$ ligand to the $\mathrm{Co}$ atom occurs (Scheme 9).

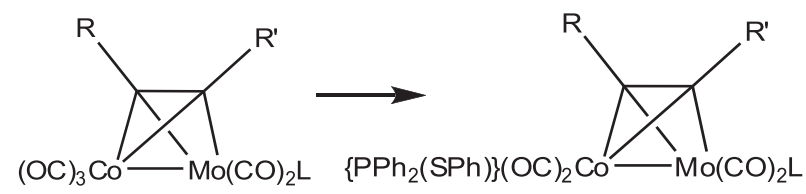

Scheme 9. Synthetic route to monosubstituted cobaltmolybdenum complexes starting from $\left[\mathrm{Co}(\mathrm{CO})_{3}\left(\mu-\mathrm{RCCR}^{\prime}\right) \mathrm{Mo}\left(\eta^{5}-\mathrm{L}\right)(\mathrm{CO})_{2}\right]$, where $\mathrm{R}=\mathrm{R}^{\prime}=\mathrm{CO}_{2} \mathrm{Me}, \mathrm{L}=\mathrm{C}_{5} \mathrm{H}_{5}[69]$; $\mathrm{R}=\mathrm{Ph}, \mathrm{R}^{\prime}=\mathrm{H}, \mathrm{L}=\mathrm{C}_{5} \mathrm{H}_{5}[70]$; $\mathrm{R}=\mathrm{R}^{\prime}=\mathrm{CO}_{2} \mathrm{Me}, \mathrm{L}=\mathrm{C}_{5} \mathrm{Me}_{5}[71]$

The ${ }^{31} \mathrm{P}\left\{{ }^{1} \mathrm{H}\right\} \mathrm{NMR}$ spectrum of $\left[\mathrm{Co}(\mathrm{CO})_{2}{ }^{-}\right.$ $\left\{(\mathrm{PhS}) \mathrm{Ph}_{2} \mathrm{P}\right\}\left\{\mu-\mathrm{C}_{2}\left(\mathrm{CO}_{2} \mathrm{Me}\right)_{2}\right\} \mathrm{Mo}\left(\eta^{5}-\mathrm{C}_{5} \mathrm{H}_{5}\right)-$
$(\mathrm{CO})_{2}$ ] displays a broad singlet resonance as expected if $\mathrm{PPh}_{2}(\mathrm{SPh})$ is bound directly to the cobalt atom through phosphorus. No disubstituted products are observed in the reaction. The potentially unfavourable interaction of the bulky ligand with the $\eta^{5}$-L group on Mo presumably inhibits substitution at this metal atom [69].

Complex $\quad\left[\mathrm{Co}(\mathrm{CO})_{2}\left\{(\mathrm{PhS}) \mathrm{Ph}_{2} \mathrm{P}\right\}\left\{\mu-\mathrm{C}_{2}-\right.\right.$ $\left.\left.\left(\mathrm{CO}_{2} \mathrm{Me}\right)_{2}\right\} \mathrm{Mo}\left(\eta^{5}-\mathrm{C}_{5} \mathrm{Me}_{5}\right)(\mathrm{CO})_{2}\right]$ (Scheme 10) has been the subject of a single-crystal X-ray diffraction study as well, and the molecular structure shows clearly coordination of the $\mathrm{PPh}_{2}(\mathrm{SPh})$ ligand to the Co atom. The structure consists of a $(\mathrm{OC})_{2} \mathrm{CoMo}(\mathrm{CO})_{2}$ skeleton which is bridged by an alkyne unit $\left[\mu-\mathrm{C}_{2}\left(\mathrm{CO}_{2} \mathrm{Me}\right)_{2}\right]$ that lies almost perpendicular to the Co-Mo single bond. The cobalt atom is further coordinated by the $\mathrm{Ph}_{2} \mathrm{P}(\mathrm{SPh})$ ligand, which bonds via the phosphorus atom and thus completes a distorted octahedral arrangement around the cobalt centre. The molybdenum atom is additionally coordinated by a pentamethylcyclopentadienyl ligand, again completing a distorted octahedral arrangement around the molybdenum centre [71].

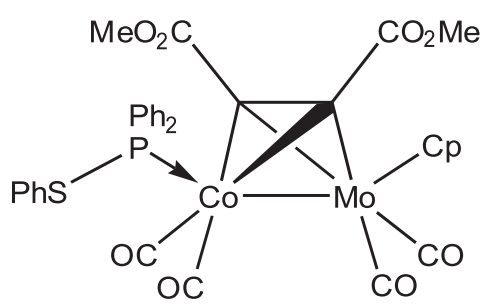

Scheme 10. Molecular structure of $\left[\mathrm{Co}(\mathrm{CO})_{2}\left\{(\mathrm{PhS}) \mathrm{Ph}_{2} \mathrm{P}\right\}\left\{\mu-\mathrm{C}_{2}\left(\mathrm{CO}_{2} \mathrm{Me}\right)_{2}\right\} \mathrm{Mo}\left(\eta^{5}-\right.\right.$ $\left.\left.\mathrm{C}_{5} \mathrm{Me}_{5}\right)(\mathrm{CO})_{2}\right]$

However, thermolysis of the monosubstituted cobalt-molybdenum complexes $\left[\mathrm{Co}(\mathrm{CO})_{2}\left\{(\mathrm{PhS}) \mathrm{Ph}_{2} \mathrm{P}\right\}\left(\mu-\mathrm{RCCR}^{\prime}\right) \mathrm{Mo}\left(\eta^{5}-\mathrm{L}\right)-\right.$ $\left.(\mathrm{CO})_{2}\right]$ in refluxing toluene yields thiolatobridged complexes, which requires the transfer of the coordinated phosphanyl group from the cobalt to the molybdenum atom (Scheme 11) [69-71]. 

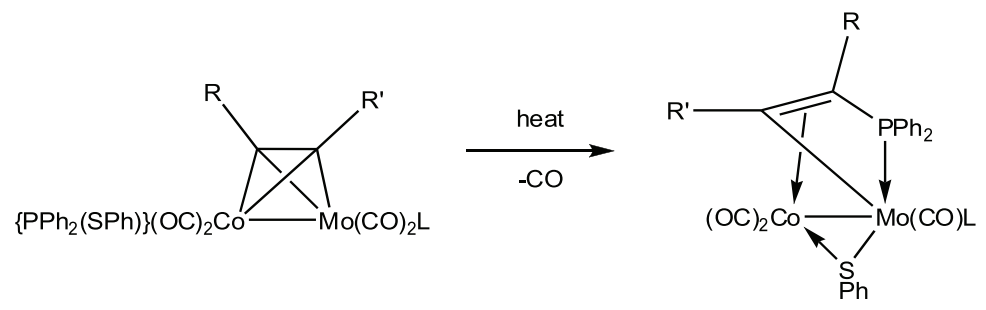

Scheme 11. Thermolysis of $\left[\mathrm{Co}(\mathrm{CO})_{2}\left\{(\mathrm{PhS}) \mathrm{Ph}_{2} \mathrm{P}\right\}\left(\mu-\mathrm{RCCR}{ }^{\prime}\right) \mathrm{Mo}\left(\eta^{5}-\mathrm{L}\right)(\mathrm{CO})_{2}\right]$

\section{SYNTHESIS AND COORDINATION CHEMISTRY OF THE LIGANDS $\mathrm{HSC}_{6} \mathrm{H}_{4}-2-\mathrm{EPh}_{2}$}

\subsection{Preparation of $\mathrm{HSC}_{6} \mathrm{H}_{4}-2-\mathrm{EPh}_{2}$}

The bidentate ligand $\mathrm{HSC}_{6} \mathrm{H}_{4}-2-\mathrm{PPh}_{2}$ (PSH) was reported by E. Block et al., along with the tri-and tetradentate phosphinoarylthiols $\left(\mathrm{HSC}_{6} \mathrm{H}_{4}-2\right)_{2} \mathrm{PPh}\left(\mathbf{P S}_{2} \mathbf{H}_{2}\right)$ and $\left(\mathrm{HSC}_{6} \mathrm{H}_{4}-2\right)_{3} \mathrm{P}$ $\left(\mathbf{P S}_{\mathbf{3}} \mathbf{H}_{3}\right)$ [72]. The chemistry of the analogous AsSH, $\mathrm{AsS}_{2} \mathbf{H}_{2}$ and $\mathrm{AsS}_{3} \mathbf{H}_{3}$ arsinoarylthiols is less explored, the synthesis of these ligands has been recently reported by our group [73]. Scheme 12 shows the above-mentioned phosphino- and arsinoarylthiols.
ESH

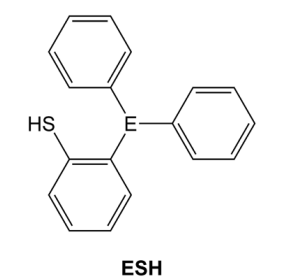

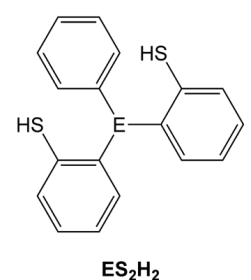

$\mathrm{ES}_{2} \mathrm{H}_{2}$

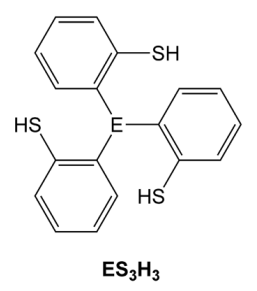

Scheme 12. Phosphino- and arsinoarylthiol ligands $(\mathrm{E}=\mathrm{As}, \mathrm{P})$
Even though S. E. Livingstone et al. reported the synthesis of a number of phosphinothiols by metal-promoted dealkylation of phosphinothioethers in 1967 [74], a general preparative route was only introduced more than 20 years later, with the discovery of the ortho-lithiation of benzenethiol [75-77]. orthoMetallation of aromatic rings is an important method in the synthesis of functional organic molecules [78-82]. Usually lithium alkyls such as $n$-butyllithium ( $\left.{ }^{n} \mathrm{BuLi}\right)$ are employed for the regioselective deprotonation of aryl moieties. Heteroatom substituents direct the lithiation to the ortho-position with respect to the neighbouring group. Thus, dilithiation of arylthiols is a key step in the preparation of ortho-functionalised arylthiols [75-82]. The basicity of the lithiation system may be tuned by the solvent and/or co-solvent, concentration, temperature or molar ratio. In some cases, the deprotonation of a weakly acidic substrate requires activation of the organolithium base by a polydentate tertiary amine like $N, N, N^{\prime}, N^{\prime}$-tetramethylethylenediamine (TMEDA) [83, 84].

The direct ortho-lithiation of lithium benzenethiolate by ${ }^{n} \mathrm{BuLi} / \mathrm{TMEDA}$ was found to be most effective in cyclohexane. This nonpolar, unreactive solvent may favour coordination of lithium cations already coordinated by the bidentate TMEDA ligands by sulfur in benzenethiolate [75].

The dilithiated species B could form via transition state A (Scheme 13). The depicted ion cluster structure B was suggested by Streitwieser $[85,86]$. The Coulomb interactions of two cations and a dicarbanion are favourable in such a geometry. The lithium cations are also coordinated by the bidentate TMEDA ligands [75].

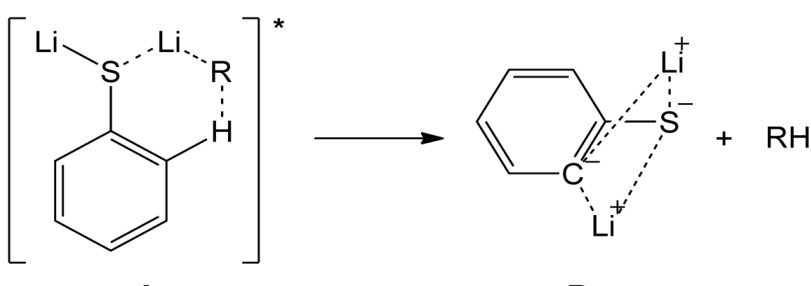

A

Scheme 13. Transition state A leading to dilithiated species B [75] 
In contrast, when an excess of ${ }^{n} \mathrm{BuLi}$ was used, deprotonation of tetramethylethylenediamine occurred and crystals of $\left[\mathrm{Li}_{3}\left\{\left(2-\mathrm{SC}_{6} \mathrm{H}_{4}\right)\right.\right.$ $\left.\left.\left(\mathrm{CH}_{2} \mathrm{MeNCH}_{2} \mathrm{CH}_{2} \mathrm{NMe}_{2}\right)(\mathrm{TMEDA})\right\}\right]_{2}$ were obtained (Scheme 14). Subsequently, it was found that $\left[\mathrm{Li}_{3}\left\{\left(2-\mathrm{SC}_{6} \mathrm{H}_{4}\right)\left(\mathrm{CH}_{2} \mathrm{MeNCH}_{2} \mathrm{CH}_{2}-\right.\right.\right.$
$\left.\left.\left.\mathrm{NMe}_{2}\right)(\mathrm{TMEDA})\right\}\right]_{2}$ is formed quantitatively and reproducibly in the reaction of $\left[\mathrm{Li}_{2}(2-\right.$ $\left.\mathrm{SC}_{6} \mathrm{H}_{4}\right)(\mathrm{TMEDA})_{1,3}$ ] with 1 equiv. of ${ }^{n} \mathrm{BuLi}$ in the presence of 1 equiv. of TMEDA. It can also be obtained by lithiation of thiophenol with 3 equiv. of ${ }^{n} \mathrm{BuLi}$ and 3 equiv. of TMEDA [87].
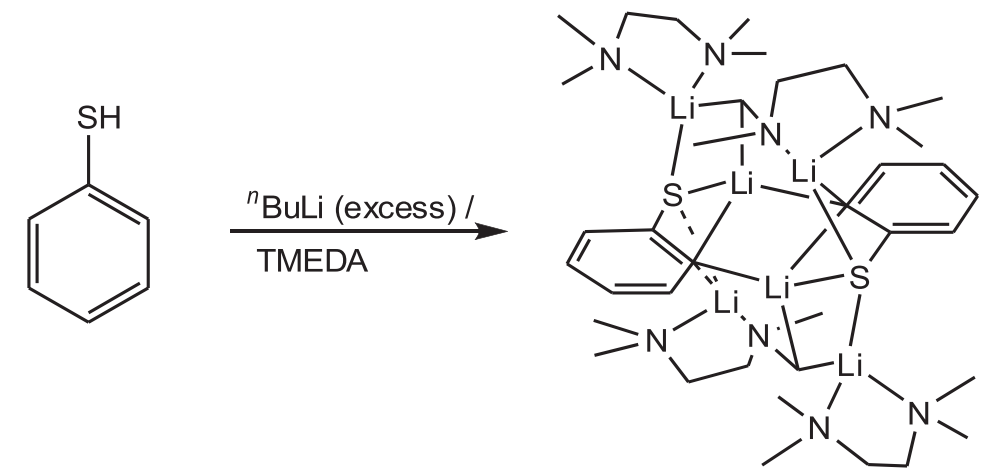

Scheme 14. Synthesis of $\left[\mathrm{Li}_{3}\left\{\left(2-\mathrm{S}-\mathrm{C}_{6} \mathrm{H}_{4}\right)\left(\mathrm{CH}_{2} \mathrm{MeNCH}_{2} \mathrm{CH}_{2}-\mathrm{NMe}_{2}\right)(\mathrm{TMEDA})\right\}\right]_{2}$

The next step in the synthesis of the bidentate $\mathrm{HSC}_{6} \mathrm{H}_{4}-2-\mathrm{EPh}_{2}$ ligands is the reaction of lithium 2-lithiobenzenethiolate ( $\mathrm{LiSC}_{6} \mathrm{H}_{4}-2-\mathrm{Li}$ ) with chlorodiphenylarsine [72] or chlorodiphenylphosphine [73]. The general reaction steps of the synthesis are presented in Scheme 15.

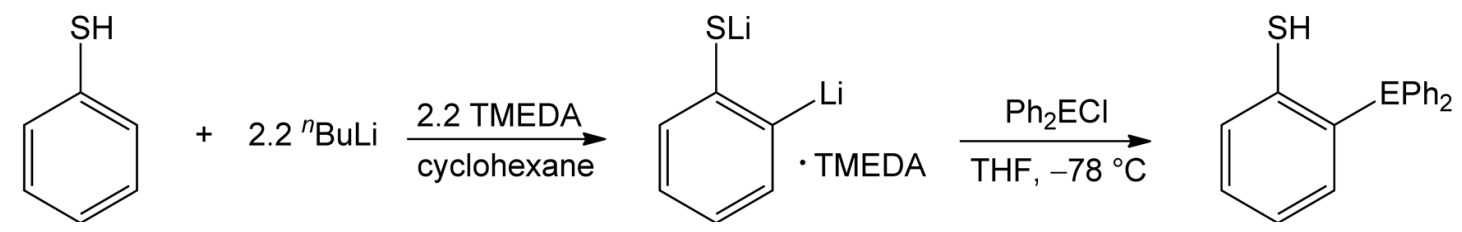

Scheme 15. Synthetic pathway for obtaining the ligands $\mathrm{HSC}_{6} \mathrm{H}_{4}-2-\mathrm{EPh}_{2}(\mathrm{E}=\mathrm{As}, \mathrm{P})$

\subsection{Coordination chemistry of $\mathrm{HSC}_{6} \mathrm{H}_{4}-2-E P h_{2}$}

The ligands $\mathrm{HSC}_{6} \mathrm{H}_{4}-2-\mathrm{EPh}_{2}$ display $-\mathrm{SH}$ functionalities which are rapidly deprotonated and may serve as versatile donor atoms in phosphanyl- and arsanylthiolato complexes. In their review article from 2000, J. R. Dilworth and N. Wheatley describe the synthesis and coordination chemistry of five types of ligands containing both phosphorus and sulfur donor centres. In the chapter dedicated to phosphinothiols which contain a phosphine group and a thiol function separated by an organic bridge, the coordination chemistry of the PSH ligand is presented in detail as well. However, this article covers all work published only until the end of 1997 [5]. Thus, the present review will give examples to illustrate the coordination preferences of the PSH ligand towards transition metals and will provide a literature update until the end of 2012. While the coordination chemistry of the PSH ligand has been comprehensively investigated with a large number of metal complexes, the analogous AsSH ligand has been less studied. Early reports on similar arsenic-containing derivatives focussed on studies of the coordination chemistry of arsanylarylthioethers [88101]. The mono- and bis-chelate complexes of dimethyl-o-methylthiophenylarsine have been reported by Livingstone et al. [88, 89, 93]. 


\section{Molybdenum complexes}

Reaction of PSH with molybdenum pentachloride yielded a mixture of $\left[\mathrm{Mo}_{2} \mathrm{Cl}_{3}\{\mu-\right.$ $S$-(PS)- $\left.\left.\kappa^{2} S, P\right\}_{3}\right]$ and $\left[\mathrm{MoCl}_{2}(\mathbf{P S})_{2}\right] \quad(\mathbf{P S}=$ $\left.\mathrm{SC}_{6} \mathrm{H}_{4}-2-\mathrm{PPh}_{2}\right)$. The thiolate acts both as ligand and reducing agent, as evidenced by the reduction of $\mathrm{Mo}$ from the 5+ state in $\mathrm{MoCl}_{5}$ to $3+$ in the former complex and to $4+$ in the latter. $\left[\mathrm{Mo}_{2} \mathrm{Cl}_{3}\left\{\mu-S \text {-(PS)- } \kappa^{2} S, P\right\}_{3}\right]$ (Scheme 16) has been crystallographically characterised and exhibits three bidentate phosphinothiolate ligands bridging a molybdenum-molybdenum triple bond and consequently producing nonequivalent metal coordination geometries, $\left[\mathrm{MoS}_{3} \mathrm{P}_{2} \mathrm{Cl}\right]$ and $\left[\mathrm{MoS}_{3} \mathrm{PCl}_{2}\right][102]$.

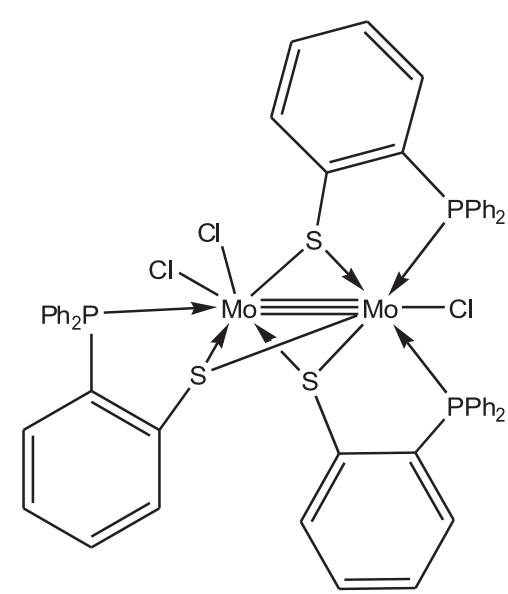

Scheme 16. Schematic drawing of $\left[\mathrm{Mo}_{2} \mathrm{Cl}_{3}\left\{\mu-S-\left(\mathrm{SC}_{6} \mathrm{H}_{4}-2-\mathrm{PPh}_{2}\right)-\kappa^{2} S, P\right\}_{3}\right]$

\section{Technetium and rhenium complexes}

Technetium and rhenium phosphinothiolate chemistry is characterised by a variety of structural types, reflecting the multiple oxidation states available to rhenium, the denticity of the ligand and the presence of steric constraints. The homoleptic technetium(III) complex of PSH, [Tc $\left.\left\{(\mathbf{P S})-\kappa^{2} S, P\right\}_{3}\right] \quad$ (Scheme 17), has been prepared and crystallographically characterised starting from $\mathrm{TcO}_{4}^{-}$[103] and from $\left[\mathrm{TcCl}_{4}\left(\mathrm{PPh}_{3}\right)_{2}\right][104]$. The rhenium(III) analogue of this compound has also been prepared and its crystal structure determined. The electrochemistry of the two complexes has been discussed [104]. Reaction of $\left[\mathrm{TcOCl}_{4}\right]^{-}$with exactly two equivalents of PSH yields the technetium(V) complex $\quad\left[\mathrm{TcOCl}\left\{(\mathbf{P S})-\kappa^{2} S, P\right\}_{2}\right] ; \quad[\mathrm{Tc}\{(\mathbf{P S})-$ $\left.\left.\kappa^{2} S, P\right\}_{3}\right]$ is formed only when an excess of ligand is used. However, the rhenium analogue cannot be prepared, as PS $^{-}$always reduces rhenium(V) to rhenium(III). The same article reports the reaction of $\left[\mathrm{TcNBr}_{2}\left(\mathrm{PPh}_{3}\right)_{2}\right]$ with PSH, which yields the nitrido technetium(V) complex [TcN $\left.\left\{(\mathbf{P S})-\kappa^{2} S, P\right\}_{2}\right]$ [104]. The synthesis of this complex was reported later on from the reaction of $\left[\mathrm{TcNCl}_{2}\left(\mathrm{PPh}_{3}\right)_{2}\right]$ with three equivalents of PSH as well [105].

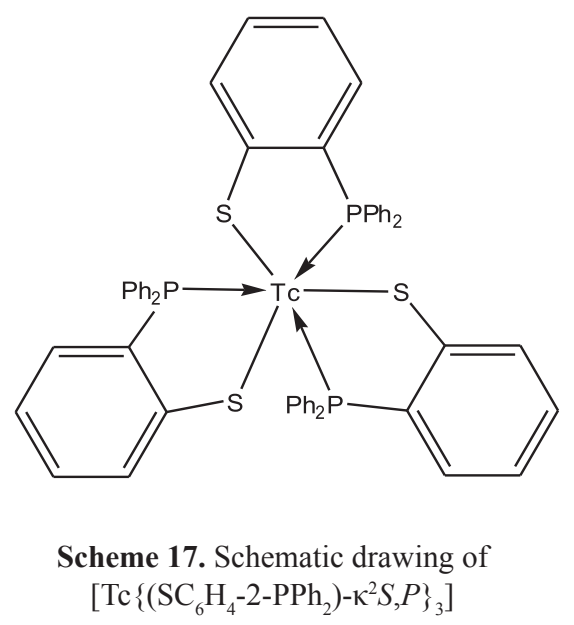

Another example of a rhenium(III) complex of $\mathbf{P S}^{-}$is $\left[\operatorname{Re}\left\{(\mathbf{P S})-\kappa^{2} S, P\right\}_{2}\left(\mathrm{~S}_{2} \mathrm{CNEt}_{2}\right)\right]$. $\mathrm{Me}_{2} \mathrm{CO}$ (Scheme 18). The crystal structure revealed a distorted octahedral geometry; the sulfur donors of the phosphinothiolate ligands adopt a cis configuration [106]. $\left[\operatorname{Re}\left\{(\mathbf{P S})-\kappa^{2} S, P\right\}-\right.$ $\left.\left\{2-\left(\mathrm{Ph}_{2} \mathrm{PO}\right) \mathrm{C}_{6} \mathrm{H}_{4} \mathrm{~S}\right\}\left(\mathrm{NNC}_{5} \mathrm{H}_{4} \mathrm{~N}\right)\left(\mathrm{HNNC}_{5} \mathrm{H}_{4} \mathrm{~N}\right)\right]$ and $\left[\operatorname{Re}\left\{(\mathbf{P S})-\kappa^{2} S, P\right\}_{2}\left(\mathrm{NNC}_{5} \mathrm{H}_{4} \mathrm{~N}\right)\right]$ were reported as the reaction products of the $\mathrm{Re}^{\mathrm{III}}$ complex $\left[\mathrm{ReCl}_{3}\left(\mathrm{NNC}_{5} \mathrm{H}_{4} \mathrm{NH}\right)\left(\mathrm{HNNC}_{5} \mathrm{H}_{4} \mathrm{~N}\right)\right]$, PSH and $\mathrm{Et}_{3} \mathrm{~N}$ in methanol. While the crystal structure of the former complex shows the rhenium atom coordinated by a bidentate phosphino thiolate ligand and by a monodentate phosphinyl thiolate ligand (through the thiolate sulfur atom), in the latter complex the metal centre is coordinated by two chelating phosphino thiolate ligands [107]. 


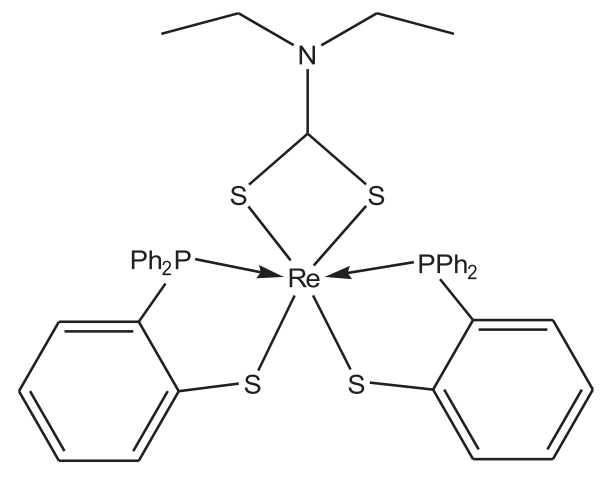

Scheme 18. Schematic drawing of $\left[\operatorname{Re}\left\{\left(\mathrm{SC}_{6} \mathrm{H}_{4}-2-\mathrm{PPh}_{2}\right)-\kappa^{2} S, P\right\}_{2}\left(\mathrm{~S}_{2} \mathrm{CNEt}_{2}\right)\right]$

The versatility of the phosphinothiolate chelates is illustrated by the oxo-chloro species $\left.\left[\mathrm{ReOCl}\{\mathbf{O P S})-\kappa^{2} S, O\right\}\left\{(\mathbf{P S})-\kappa^{2} S, P\right\}\right]$ and the binuclear $\left[\operatorname{Re}_{2} \mathrm{O}_{5}-\left\{(\mathbf{P S})-\kappa^{2} S, P\right\}_{2}\right]$ as well, which originate from the same reaction of ammonium perrhenate and PSH. The crystal structure analysis shows the rhenium $(\mathrm{V})$ centre of the former complex in a distorted octahedral environment. The binuclear rhenium species has two unique metal environments. The structure may be described as a mixed-valence species constructed from a distorted octahedral $\mathrm{Re}^{\mathrm{V}}$ site corner-sharing with a tetrahedral $\mathrm{Re}^{\mathrm{VII}}$ site [108].

\section{Iron and ruthenium complexes}

$\left[\mathrm{Fe}\left\{(\mathbf{P S})-\kappa^{2} S, P\right\}_{3}\right]$ can be prepared in good yield by the electrochemical oxidation of an iron anode in a cell containing an acetonitrile solution of the PSH ligand. The direct reaction of anhydrous $\mathrm{FeCl}_{2}$ with an excess of PSH in acetonitrile gives impure products unless an additional phosphine ligand is present. Alternatively, $\mathrm{CO}$ can act as an additional ligand to give an $\mathrm{Fe}^{\mathrm{II}}$ carbonyl complex; when the reaction was carried out in acetonitrile saturated with $\mathrm{CO}$ an orange solid was produced, which proved to be $\left[\mathrm{Fe}(\mathrm{CO})_{2}\left\{(\mathbf{P S})-\kappa^{2} S, P\right\}_{2}\right]$. The complex can be stored under $\mathrm{CO}$ but otherwise rapidly decomposes to leave a $\mathrm{CO}$-free, pale brown polymeric solid [109].

PSH oxidatively substitutes trimethylphosphine in $\left[\mathrm{Fe}\left(\mathrm{PMe}_{3}\right)_{4}\right]$ to form $f a c-[\mathrm{FeH}\{(\mathbf{P S})-$ $\left.\left.\kappa^{2} S, P\right\}\left(\mathrm{PMe}_{3}\right)_{3}\right]$. None of the two possible mer isomers is observed. However, under 1 bar of $\mathrm{CO}$ $f a c-\left[\mathrm{FeH}\left\{(\mathbf{P S})-\kappa^{2} S, P\right\}\left(\mathrm{PMe}_{3}\right)_{3}\right]$ is converted to the monocarbonyl derivative $\left[\mathrm{FeH}\left\{(\mathbf{P S})-\kappa^{2} S, P\right\}\right.$ $\left.(\mathrm{CO})\left(\mathrm{PMe}_{3}\right)_{2}\right]$ which in solution forms mixtures of two isomers [110].

Reaction of $\left[\mathrm{RuCl}_{2}\left(\mathrm{PPh}_{3}\right)_{3}\right]$ with PS $^{-}$yields the anionic ruthenium(II) complex $[\mathrm{Ru}\{(\mathbf{P S})$ $\left.\left.\kappa^{2} S, P\right\}_{3}\right]^{-}$. This is readily oxidised in air, first to the neutral ruthenium(III) analogue $[\mathrm{Ru}\{(\mathbf{P S})$ $\left.\kappa^{2} S, P\right\}_{3}$ ], and then to the sulfur-oxidised complex $\left[\mathrm{Ru}\left\{(\mathbf{P S})-\kappa^{2} S, P\right\}\left\{(\mathbf{P S O})-\kappa^{2} S, P\right\}\left\{\left(\mathbf{P S O}_{2}\right)-\kappa^{2} S, P\right\}\right]$ (Scheme 19) [111]. This latter complex, which has been crystallographically characterised, shows rare examples of $S$-coordinated sulfenate and sulfinate groups.

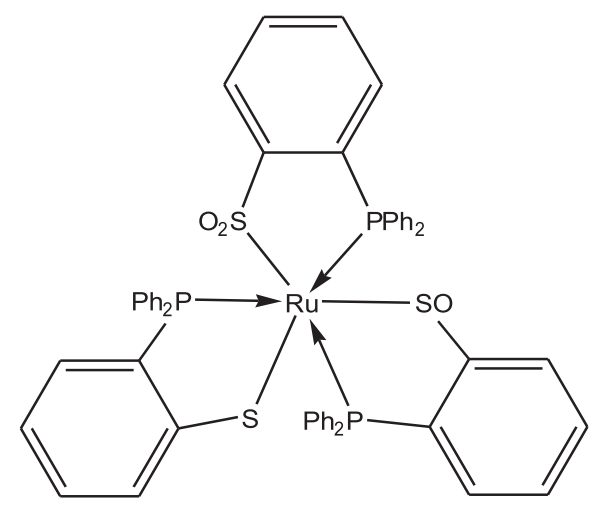

Scheme 19. Schematic drawing of $\left[\mathrm{Ru}\left\{\left(\mathrm{SC}_{6} \mathrm{H}_{4}-2-\mathrm{PPh}_{2}\right)-\kappa^{2} S, P\right\}\left\{\left(\mathrm{OSC}_{6} \mathrm{H}_{4}-2-\mathrm{PPh}_{2}\right)-\kappa^{2} S, P\right\}\right.$ $\left.\left\{\left(\mathrm{O}_{2} \mathrm{SC}_{6} \mathrm{H}_{4}-2-\mathrm{PPh}_{2}\right)-\kappa^{2} S, P\right\}\right]$

\section{Cobalt, rhodium and iridium complexes}

The reaction of $\mathrm{CoCl}_{2}$ with the potentially bidentate ligand PSH in methanol in the presence of $\mathrm{NEt}_{3}$ led to the formation of the paramagnetic green compound $\left[\mathrm{Co}\{\mathbf{P S}\}_{2}\right]$. The structural studies of $\left[\mathrm{Co}\left\{\left(\mathrm{SC}_{6} \mathrm{H}_{4}-2-\mathrm{P}(\mathrm{O})\right.\right.\right.$ $\left.\left.\mathrm{Ph}_{2}\right)-\kappa^{2} S, O\right\}_{2}$ ] show the presence of a $\mathrm{Co}^{\mathrm{II}}$ ion with a tetrahedral coordination environment. The incorporated oxygen could originate from the crystallization process [18]. Such facile oxidation from phosphine to phosphine oxide has been observed in other compounds containing this type of ligand $[102,108]$.

The electrochemical oxidation of anodic cobalt in a solution of PSH in acetonitrile 
affords the complex $\left[\mathrm{Co}\{\mathbf{P S}\}_{2}\right]$, too, as green crystalline needles [112].

The reaction of a series of acyl(hydrido) cobalt(III) complexes with PSH generated two types of cobalt(III) chelate complexes, one cobalt(I) chelate complex and one cobalt(II) chelate complex. The complex bearing a soft/ soft $[\mathrm{P}, \mathrm{S}]$ chelating ligand and a soft low-valent cobalt(I) central atom was obtained in higher yield, while the expected products with a soft/ soft $[\mathrm{P}, \mathrm{S}]$ chelating ligand and a hard highvalent cobalt(III) central atom show low yields [113].

PSH and AsSH react with $\left[\{\mathrm{RhCl}(\mathrm{cod})\}_{2}\right]$ to give $\left[\mathrm{Rh}\left\{\mu-S-(\mathbf{E S})-\kappa^{2} S, E\right\}_{2} \mathrm{Rh}(\operatorname{cod})\right](\operatorname{cod}=$ 1,5-cyclooctadiene), in which the two rhodium atoms are bridged by the thiolato groups of the ligands. One rhodium atom is coordinated by both ligands $\left(\kappa^{2} S, E\right)$ and the other rhodium atom by an additional 1,5-cyclooctadiene molecule, resulting in square-planar coordination geometry of both rhodium(I) centres (Scheme 20). Theoretical studies confirmed the existence of metal-metal interactions between the two rhodium atoms of both complexes. $[\mathrm{Rh}(\mu-$ $S$-(AsS) $\left.\left.-\kappa^{2} S, A s\right)_{2} \operatorname{Rh}(\operatorname{cod})\right]$ is active in the hydrogenation of olefins [114].

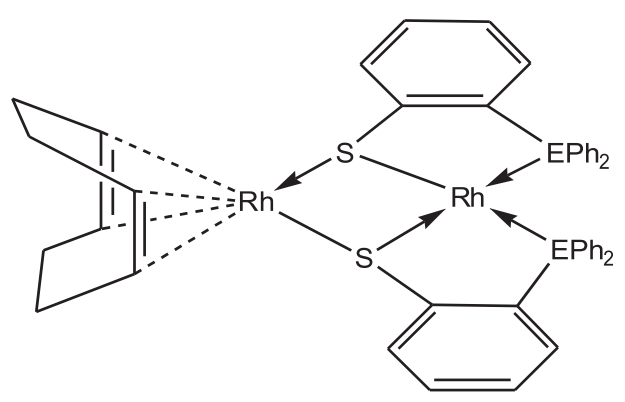

Scheme 20. Schematic drawing of $\left[\mathrm{Rh}\left\{\mu-S-\left(\mathrm{SC}_{6} \mathrm{H}_{4}-2-\mathrm{EPh}_{2}\right)-\kappa^{2} S, E\right\}_{2} \mathrm{Rh}(\mathrm{cod})\right]$

$\left[\operatorname{Rh}\left\{(\mathbf{P S})-\kappa^{2} S, P\right\}(\mathrm{CO})\right]_{2}$ was prepared by reaction of PSH with $\left[\left\{\mathrm{RhCl}(\mathrm{CO})_{2}\right\}_{2}\right]$. The solid-state structure shows a sulfur-bridged dimer (Scheme 21), which proved to be an efficient catalyst for the carbonylation of methanol to acetic acid, showing up to four times the activity of the classical catalyst $\left[\mathrm{RhI}_{2}(\mathrm{CO})_{2}\right]^{-}[115,116]$. $\left[\mathrm{M}\left\{(\mathbf{P S})-\kappa^{2} S, P\right\}(\mathrm{cod})\right]_{2}(\mathrm{M}=\mathrm{Rh}, \mathrm{Ir})$ were prepared by the reaction of $\mathbf{P S}^{-}$with $\left[\{\mathrm{MCl}(\operatorname{cod})\}_{2}\right]$. Based on the NMR data, the cyclooctadiene ligand is $\eta^{2}$ coordinated and the complexes are assumed to be sulfur-bridged dimers, as are the carbonyl species [115].

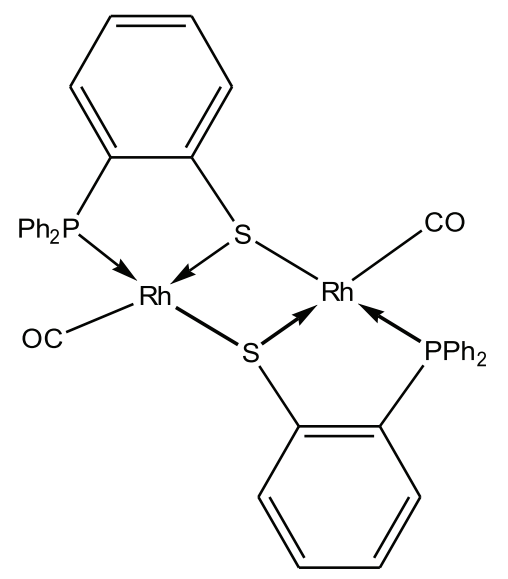

Scheme 21. Schematic drawing of $\left[\mathrm{Rh}\left\{\left(\mathrm{SC}_{6} \mathrm{H}_{4}-2-\mathrm{PPh}_{2}\right)-\kappa^{2} S, P\right\}(\mathrm{CO})\right]_{2}$

The mononuclear $\mathrm{Rh}^{\mathrm{I}}$ and $\mathrm{Ir}^{\mathrm{I}}$ complexes $\left[\mathrm{M}\left\{(\mathbf{P S})-\kappa^{2} S, P\right\}(\mathrm{CO})\left(\mathrm{PPh}_{3}\right)\right]$ reversibly bind sulfur dioxide, and the iridium complex adds dihydrogen [117]. Reaction of an excess of PSH with $\mathrm{IrCl}_{3}$ in the presence of a base led to $\left[\operatorname{Ir}\left\{(\mathbf{P S})-\kappa^{2} S, P\right\}_{3}\right]$, which shows the ligands coordinating iridium in an octahedral fashion [118]. The reaction of $\left[\mathrm{RhCl}\left(\mathrm{PPh}_{3}\right)_{3}\right]$ with excess of PS $^{-}$led to the formation of the rhodium(III) complex $\left[\mathrm{Rh}\left\{(\mathbf{P S})-\kappa^{2} S, P\right\}_{3}\right]$. The mixed-ligand $\mathrm{Ir}^{\mathrm{III}}$ complex $\left[\mathrm{IrCl}_{2}\left\{(\mathbf{P S})-\kappa^{2} S, P\right\}\left(\mathrm{PMe}_{2} \mathrm{Ph}\right)_{2}\right]$ has also been crystallographically characterised [118].

\section{Nickel, palladium and platinum complexes}

Most of the known complexes of nickel, palladium and platinum with phenylene-bridged phosphanyl- or arsanylthiolate ligands have been prepared by dealkylation of the corresponding thioether complexes. Scheme 22 shows the schematic drawing of the reported bis-chelates. trans- $\left[\operatorname{Pd}\left\{(\mathbf{P S})-\kappa^{2} S, P\right\}_{2}\right]$ was described for the first time as the product of the S-dealkylation of 
a cationic thioether complex in a Menschutkintype reaction [119]. The identification and the molecular structure of the cis isomer were reported afterwards [120-122]. Studies concerning the structural preference of the palladium bis-chelate showed slow isomerisation from the cis geometry in solution, until a cis/trans equilibrium mixture could be observed [120]. Analogously to the palladium bis-chelate, $\left[\mathrm{Pt}\left\{(\mathbf{P S})-\kappa^{2} S, P\right\}_{2}\right]$ was also synthesised for the first time by an S-dealkylation process [123], but its stereochemistry could not be determined. Later it was assumed to be trans [124], but in 2003 cis-[Pt $\left.\left\{(\mathbf{P S})-\kappa^{2} S, P\right\}_{2}\right]$ was reported, as the product of a transmetallation reaction [121]. trans-[Ni\{(PS)- $\left.\left.\kappa^{2} S, P\right\}_{2}\right]$ has been structurally characterised in green, monoclinic [125] and brown, triclinic [126] modifications, while the cis geometry of the nickel complex could not be unequivocally confirmed by X-ray diffraction studies [121]. However, the reaction of $\mathrm{HSC}_{6} \mathrm{H}_{4}-2-\mathrm{P}(\mathrm{Biph})$ (BiphPSH, Biph = $1,1^{\prime}$-biphenyl-2,2'-diyl) with $\mathrm{NiCl}_{2} \cdot 6 \mathrm{H}_{2} \mathrm{O}$ in a $2: 1$ ratio and in the presence of $\mathrm{NEt}_{3}$ led to exclusive formation of the cis isomer of the square-planar complex cis-[Ni\{(BiphPS $\left.\left.)-\kappa^{2} S, P\right\}_{2}\right]$. Density functional calculations support the assumption that this is probably due to intramolecular $\pi-\pi$ interaction of the biphenyl groups, which results in enhanced stability of the cis isomer. $c i s-\left[\mathrm{Ni}\left\{(\mathbf{B i p h P S})-\kappa^{2} S, P\right\}_{2}\right]$ is the first example of a structurally characterised mononuclear cis-bis(phosphanylthiolato)nickel(II) complex. The reaction of BiphPSH with $\mathrm{Na}_{2}\left[\mathrm{PdCl}_{4}\right]$ and $\left[\mathrm{PtI}_{2}(\operatorname{cod})\right](\operatorname{cod}=1,5$-cyclooctadiene $)$ also led to the cis species $\left[\mathrm{M}\left\{(\mathbf{B i p h P S})-\kappa^{2} S, P\right\}_{2}\right](\mathrm{M}=$ $\mathrm{Pd}, \mathrm{Pt})$. Small amounts of the trinuclear complex $\left[\left\{\mathrm{PtI}\left(\left(\mu-S-\mathrm{SC}_{6} \mathrm{H}_{4}-2-\mathrm{PBiph}\right)-\mathrm{k}^{2} S, P\right)\right\}_{3}\right]$ are also formed besides the mononuclear platinum bischelate complex [127].

Treating pentane solutions of $\left[\mathrm{Ni}\left(\mathrm{PMe}_{3}\right)_{4}\right]$ with PSH gave the red complex $[\mathrm{NiH}(\mathbf{P S})$ $\left.\left(\mathrm{PMe}_{3}\right)_{2}\right]$. This compound is very unstable in solution, and within several minutes dissociation of $\mathrm{PMe}_{3}$ ligands induces transformation of the complex into $\left[\mathrm{Ni}(\mathbf{P S})\left(\mathrm{PMe}_{3}\right)_{2}\right]$ and bis-chelate [Ni $\left.\left\{\text { (PS) }-\kappa^{2} S, P\right\}_{2}\right]$ [121, 125], accompanied by the appearance of a green colour and evolution of $\mathrm{H}_{2}[21,25]$. [ $\left.\mathrm{NiMe}(\mathrm{OMe})\left(\mathrm{PMe}_{3}\right)\right]$ or $\left[\mathrm{NiMe}_{2}\left(\mathrm{PMe}_{3}\right)_{3}\right]$ reacts with $\mathbf{P S H}$ to form complexes $\left[\mathrm{NiMe}(\mathbf{P S})\left(\mathrm{PMe}_{3}\right)\right]$ and $[\mathrm{NiMe}(\mathbf{P S})$ $\left.\left(\mathrm{PMe}_{3}\right)_{2}\right][21]$.

The electrochemical oxidation of anodic nickel in a solution of PSH in acetonitrile also led to the formation of the previously mentioned bis-chelate [Ni $\left.\left\{(\mathbf{P S})-\mathrm{k}^{2} S, P\right\}_{2}\right][112]$.

Reactions of the arsinoarylthiol ligand AsSH with group 10 metal(II) complexes in a 2:1 ratio afforded square-planar complexes $\left[\mathrm{M}\left\{(\mathbf{A s S})-\kappa^{2} S, A s\right\}_{2}\right](\mathrm{M}=\mathrm{Ni}, \mathrm{Pd}, \mathrm{Pt})$. In the cases of nickel and platinum complexes, only one isomer was isolated (trans and cis, respectively). With palladium, initially the cis isomer was formed and underwent slow isomerisation to the trans isomer in solution. Besides the mononuclear platinum bis-chelate complex, a small amount of the unexpected trinuclear complex $\quad\left[\left\{\mathrm{PtI}\left(\mu-S-\mathrm{SC}_{6} \mathrm{H}_{4}-2-\mathrm{AsPh}_{2}-\kappa^{2} S, P\right)\right\}_{3}\right]$ was also formed. Density functional theory cal-

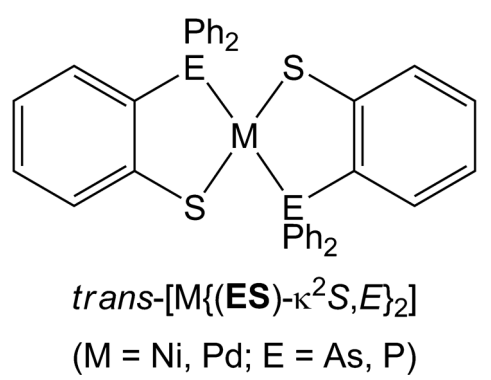

Scheme 22. Schematic drawing of Ni, $\mathrm{Pd}$ and Pt complexes of $\mathrm{HSC}_{6} \mathrm{H}_{4}-2-\mathrm{EPh}_{2}$ 
culations supported a dissociative mechanism for the isomerisation of the palladium(II) complexes [73].

\section{Copper, silver and gold complexes}

The reaction of PSH with $\left[\mathrm{Cu}(\mathrm{NCMe})_{4}\right]$ $\left[\mathrm{PF}_{6}\right]$, followed by addition of one equivalent of 2,2'-bipyridine (bpy) did not result in the formation of $[\mathrm{Cu}(\mathbf{P S})(\text { bpy })]^{+}$, but in oxidative coupling of the thiol to give PS-SP [128]. It has been previously observed that the electrochemical oxidation of PSH proceeds with oxidation at phosphorus in addition to oxidative coupling to give a disulfide [129]. The neutral complex $[\mathrm{Cu}\{\mathbf{P S}\}]$ was obtained by electrochemical oxidation of anodic copper metal in a cell containing the ligand PSH dissolved in acetonitrile. The compound was obtained as an insoluble solid due to a polymerisation process in which the thiolato sulfur atoms act as bridges between the metal centres. In order to increase the solubility to obtain single crystals suitable for X-ray diffraction, the presence of co-ligands in the cell that can coordinatively saturate the metal and to some extent inhibit the polymerisation process, was necessary. The addition of donor ligands such as $\mathrm{PPh}_{3}$, dppe or dppm led to the formation of the following species: $\left[\mathrm{Cu}_{2}\{\mu-\right.$ $S$-(PS)-k $\left.\left.{ }^{2} P, S\right\}_{2}\left(\mathrm{PPh}_{3}\right)_{2}\right]$ (Scheme 23), $\left[\mathrm{Cu}_{2}\{\mu-\right.$ $S$-(PS)-k $\left.{ }^{2} P, S\right\}_{2}\left(\mu\right.$-dppe)] and $\left[\mathrm{Cu}_{2}\{\mu-S\right.$-(PS)$\left.\left.\mathrm{k}^{2} P, S\right\}_{2}(\mu-\mathrm{dppm})\right][18]$.

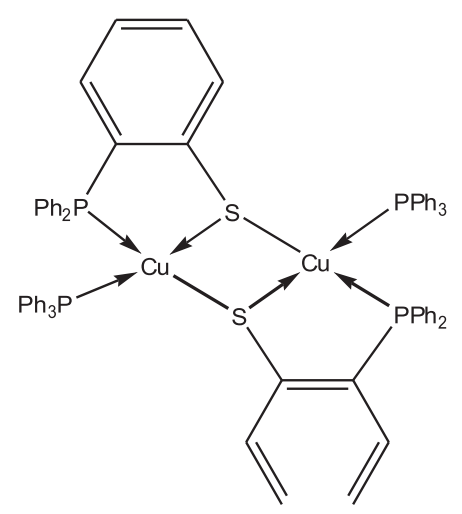

Scheme 23. Schematic drawing of $\left[\mathrm{Cu}_{2}\left\{\left(\mu-S-\mathrm{SC}_{6} \mathrm{H}_{4}-2-\mathrm{PPh}_{2}\right)-\kappa^{2} S, P\right\}_{2}\left(\mathrm{PPh}_{3}\right)\right]_{2}$
The silver complex of the anionic form of PSH has been synthesised via an electrochemical procedure. Attempts to obtain crystals suitable for X-ray studies were unsuccessful; the structure was assumed to be tetrameric or polymeric [130].

Reaction of PS $^{-}$with $\mathrm{H}\left[\mathrm{AuCl}_{4}\right]$ gave the square-planar $\mathrm{Au}^{\mathrm{III}}$ complex $\left.\mathrm{Au}\left\{(\mathbf{P S})-\kappa^{2} S, P\right\}_{2}\right]$ $\mathrm{BPh}_{4}$, which has been crystallographically characterised and shows a reversible oneelectron reduction in acetonitrile solution [124]. The crystal structure of $\left[\mathrm{Au}\left(\mathrm{C}_{6} \mathrm{~F}_{5}\right)_{3}\{(\mathbf{P S H})-\kappa P\}\right]$ was also reported. This complex was obtained from the reaction of $\mathrm{PSH}$ with $\left[\mathrm{Au}\left(\mathrm{C}_{6} \mathrm{~F}_{5}\right)_{3}(\mathrm{tht})\right]$, and still contains the protonated $\mathrm{SH}$ group as a potential site for further reactions [131].

\section{Zinc, cadmium and mercury complexes}

The electrochemical oxidation of anodic zinc or cadmium in a cell containing PSH in acetonitrile gave the crystalline air-stable complexes $\left[\mathrm{Zn}\{\mathbf{P S}\}_{2}\right]$ and $\left[\mathrm{Cd}\{\mathbf{P S}\}_{2}\right]$. Concentration of the mother liquor from the synthesis of $\left[\mathrm{Cd}\{\mathbf{P S}\}_{2}\right]$ in air yielded crystals of the dimeric phosphine oxide complex $\left[\mathrm{Cd}_{2}\left\{\left(\mu-S-\mathrm{SC}_{6} \mathrm{H}_{4}\right.\right.\right.$ $\left.\left.\left.2-\mathrm{P}(\mathrm{O}) \mathrm{Ph}_{2}\right)-\kappa^{2} S, O\right\}_{4}\right]$. The solid-state structure consists of dimers in which two thiolate sulfur atoms of two ligands bridge the two cadmium centres (Scheme 24). The incorporation of additional bidentate ligands to the cell allows the synthesis of cadmium mixed-ligand complexes such as $\left[\mathrm{Cd}\{\mathbf{P S}\}_{2}\right.$ (bpy)] (bpy $=2,2$ '-bipyridine) and $\left[\mathrm{Cd}\{\mathbf{P S}\}_{2}\right.$ (phen) $]$ (phen =1,10-phenanthroline). Attempts to obtain mixed-ligand complexes in the case of zinc were unsuccessful, probably due to the different atomic sizes of zinc and cadmium, which makes the zinc atom more reluctant than the cadmium atom to achieve an octahedral environment, especially in the case of bulky ligands such as phosphanylarylthiol [132].

P. Fernández et al. also prepared the complex $\left[\mathrm{Cd}\{\mathbf{P S}\}_{2}\right]$, by oxidation of a cadmium anode in a cell containing a solution of PSH in acetonitrile. In this case, however, crystals 


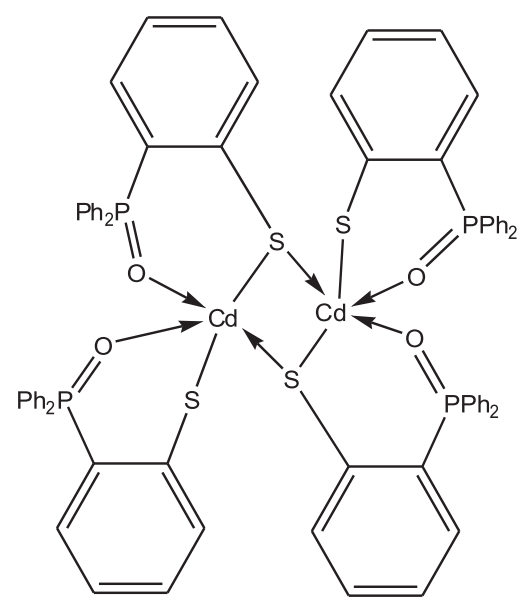

Scheme 24. Schematic drawing of $\left[\mathrm{Cd}_{2}\left\{\left(\mu-S-\mathrm{SC}_{6} \mathrm{H}_{4}-2-\mathrm{P}(\mathrm{O}) \mathrm{Ph}^{2}\right)-\kappa^{2} S, O_{4}\right\}_{2}\left\{\left(\mathrm{SC}_{6} \mathrm{H}_{4}-2-\mathrm{P}(\mathrm{O}) \mathrm{Ph}_{2}\right)-\right.\right.$ $\left.\left.\kappa^{2} S, O\right\}_{2}\right]$

of the oxygen-containing compound $\left[\mathrm{Cd}_{2}\{(\mu-\right.$ $S$-PS $\left.)-\kappa^{2} S, P\right\}_{3}\left\{\left(\mu-S\right.\right.$ - $\left.\mathrm{SC}_{6} \mathrm{H}_{4}-2-\mathrm{P}(\mathrm{O}) \mathrm{Ph}_{2}\right)-$ $\left.\left.\kappa^{2} S, O\right\}\right] \cdot \mathrm{CH}_{3} \mathrm{CN}$ were obtained by concentration of the mother liquor as shown by X-ray crystallography [133].

Mercury(II) and ethylmercury(II) complexes were obtained by slow addition of a solution of mercury acetate or a solution of ethylmercury(II) chloride in methanol to a stirred solution of PSH and triethylamine in the same solvent. Both reactions led to the formation of solids for which the analytical data are consistent with $\left[\mathrm{Hg}\{\mathbf{P S}\}_{2}\right]$ and [EtHg $\{\mathbf{P S}\}]$, respectively. The X-ray structure of $\left[\mathrm{Hg}\left\{(\mathbf{P S})-\kappa^{2} S, P\right\}_{2}\right]$ shows a mercury atom coordinated by two monoanionic bidentate ligands, while the structure of $\left[\mathrm{EtHg}\left\{\left(\mathrm{SC}_{6} \mathrm{H}_{4}-2-\mathrm{P}(\mathrm{O})\right.\right.\right.$ $\left.\left.\mathrm{Ph}_{2}\right)-\kappa S\right\}$ ] shows the oxidised phosphine. In addition, in the reaction of $\mathrm{EtHgCl}$ with PSH, cleav- age of the $\mathrm{Hg}-\mathrm{C}$ bond was observed with the formation of $\left[\mathrm{Hg}\{\mathbf{P S}\}_{2}\right]$ and the corresponding hydrocarbon [133]. It has been demonstrated that the activation of the $\mathrm{Hg}-\mathrm{C}$ bond and its cleavage is related to the coordination of mercury by strongly donating ligands such as $\mathrm{N}\left(\mathrm{CH}_{2} \mathrm{CH}_{2} \mathrm{PPh}_{2}\right)_{3}$ [134], 2-(2'-pyridyl)quinoxaline [135], diphenyldithiophosphinic acid [136] and thioethers [137].

\section{Gallium and indium complexes}

The (organo)gallium compounds $\mathrm{GaCl}\{(\mathbf{P S})--$ $\left.\kappa^{2} S, P\right\}_{2}, \mathrm{Ga}\left\{(\mathbf{P S})-\kappa^{2} S, P\right\}\{(\mathbf{P S})-\kappa S\}_{2}, \mathrm{GaMe}_{2}-$ $\left\{(\mathbf{P S})-\kappa^{2} S, P\right\}, \mathrm{Ga}^{t} \mathrm{Bu}_{2}\left\{(\mathbf{P S})-\kappa^{2} S, P\right\}, \mathrm{Ga}^{\imath} \mathrm{Bu}\{(\mathbf{P S})-$ $\left.\kappa^{2} S, P\right\}\{(\mathbf{P S})-\kappa S\}, \quad\left[\mathrm{GaMe}_{2}\left\{\left(\mu_{2}-\mathbf{A s S}\right)-\kappa S\right\}\right]_{2}, \quad$ and $\mathrm{Ga}{ }^{7} \mathrm{Bu}\left\{(\mathbf{A s S})-\kappa^{2} S, A s\right\}\{(\mathbf{A s S})-\kappa S\}$ were obtained from the reaction of $\mathbf{P S H}$ and $\mathbf{A s S H}$ with $\mathrm{GaCl}_{3}$ (the first two) or $\mathrm{GaR}_{3}\left(\mathrm{R}=\mathrm{Me},{ }^{t} \mathrm{Bu}\right.$; the last five) in different molar ratios and under different reaction conditions. Ga $\left\{(\mathbf{P S})-\kappa^{2} S, P\right\}\{(\mathbf{P S})-$ $\kappa S\}_{2}$ was also obtained from $\mathrm{Li}(\mathbf{P S})$ and $\mathrm{GaCl}_{3}$ (3.5:1). Although similar phosphorus and arsenic ligands usually exhibit the same coordination behaviour toward the same metal complex fragment, different structures are observed here: a monomeric structure with a chelating phosphinoarylthiolate ligand in $\mathrm{GaMe}_{2}\{(\mathbf{P S})-$ $\left.\kappa^{2} S, P\right\}$ and a dimeric arsinoarylthiolato-bridged complex $\left[\mathrm{GaMe}_{2}\left\{\left(\mu_{2} \text {-AsS }\right)-\kappa S\right\}\right]_{2}$ (Scheme 25) [22].

B3LYP/6-31G(d) calculations show that although the dimer is thermodynamically favoured for both ligands, the formation of $\mathrm{GaMe}_{2}\left\{(\mathbf{P S})-\kappa^{2} S, P\right\}$ is due to the combination<smiles>C[Ge]1(C)Pc2ccccc2S1</smiles>

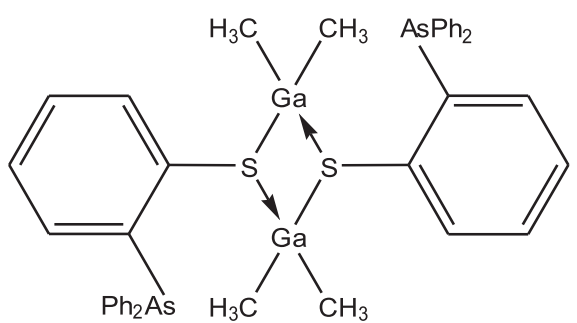

Scheme 25. Schematic drawing of $\mathrm{GaMe}_{2}\left\{\left(\mathrm{SC}_{6} \mathrm{H}_{4}-2-\mathrm{PPh}_{2}\right)-\kappa^{2} S, P\right\}$ and $\left[\mathrm{GaMe}_{2}\left\{\left(\mu_{2}-\mathrm{SC}_{6} \mathrm{H}_{4}-2-\mathrm{AsPh}_{2}\right)-\kappa S\right\}\right]_{2}$ 
of higher stability of the chelate compared with the monodentate phosphorus ligand and a higher barrier for the ring opening of the $\mathbf{P S}^{-}$ than of the $\mathbf{A s S}^{-}$chelate [22].

The complex $\left[\operatorname{In}\left\{(\mathbf{P S})-\kappa^{2} S, P\right\}_{3}\right]$ has been prepared by electrochemical oxidation of anodic indium metal in an acetonitrile solution of the phosphanylarylthiol ligand PSH. The complex exhibits distorted six-coordinate geometry based on the $\operatorname{InS}_{3} \mathrm{P}_{3}$ core. The compound may be regarded as potential MOCVD precursor to III-V semiconductors [138].

\section{Tin complexes}

The diorganotin derivatives $\left[\mathrm{R}_{2} \mathrm{Sn}\{(\mathbf{P S})\right.$ $\kappa S\}_{2}$ ] $(\mathrm{R}=\mathrm{Me}, \mathrm{Ph})$ have been prepared by treating the corresponding diorganotin(IV) chlorides $\mathrm{R}_{2} \mathrm{SnCl}_{2}$ with PSH. For the latter, the crystal structure shows a tetrahedrally coordinated tin atom, the two PS $^{-}$ligands acting as monodentate ligands coordinating via sulfur [139]. The tin compounds were used for the preparation of heteronuclear complexes, and the crystal structure of $\left[{ }^{t} \mathrm{Bu}_{2} \mathrm{Sn}\left\{(\mathbf{P S}) \mathrm{Au}\left(\mathrm{C}_{6} \mathrm{~F}_{5}\right)\right\}_{2}\right]$ was determined [140].

\section{Bismuth complexes}

The neutral bismuth(III) complex [Bi $\{$ (PS)$\left.\left.\kappa^{2} S, P\right\}_{3}\right]$ (Scheme 26) has been prepared by direct reaction of bismuth(III) chloride and the PSH ligand in methanol in the presence of triethylamine. The crystal structure of $[\mathrm{Bi}\{(\mathbf{P S})-$ $\left.\left.\kappa^{2} S, P\right\}_{3}\right]$ consists of discrete molecules with the bismuth atom bonded by three bidentate phosphinothiolate ligands through the sulfur and phosphorus atoms in a chelating manner. The coordination geometry around the metal ion is best described as distorted octahedral [141].

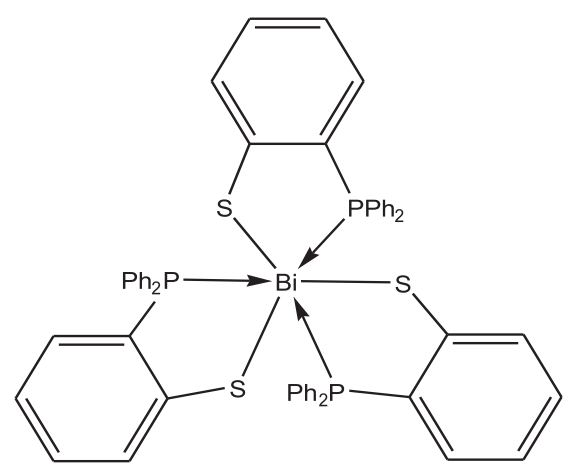

Scheme 26. Schematic drawing of $\left[\mathrm{Bi}\left\{\left(\mathrm{SC}_{6} \mathrm{H}_{4}-2-\mathrm{PPh}_{2}\right)-\kappa^{2} S, P\right\}_{3}\right]$

\section{SYNTHESIS AND COORDINATION CHEMISTRY OF THE LIGAND $1-\mathrm{Ph}_{2} \mathrm{AsSC}_{6} \mathrm{H}_{4}-2-\mathrm{PPh}_{2}$}

\subsection{Preparation of 1-Ph $\mathrm{AsSC}_{6} \mathrm{H}_{4}-2-\mathrm{PPh}_{2}$}

The synthesis of P,SAs starts with the ortho-lithiation of the thiophenol followed by reaction with $\mathrm{Ph}_{2} \mathrm{PCl}$. The monolithiation of the resulting phosphanylarylthiol PSH allowed introduction of the third donor group through reaction with $\mathrm{Ph}_{2} \mathrm{AsCl}$ (Scheme 27) [142].<smiles></smiles>

Scheme 27. Synthetic route towards $1-\mathrm{Ph}_{2} \mathrm{AsSC}_{6} \mathrm{H}_{4}-2-\mathrm{PPh}_{2}$ 


\subsection{Coordination chemistry of $1-\mathrm{Ph}_{2} \mathrm{AsSC}_{6} \mathrm{H}_{4}-2-\mathrm{PPh}_{2}$}

P,SAs combines the properties of phenylthio(diphenyl)arsine and 2-diphenylphosphanylbenzenethiol, and may also exhibit a wide range of possible bonding modes and allow the effect of the $\mathrm{PPh}_{2}$ group in the ortho position on the cleavage of the As-S bond to be studied. Furthermore, it could act as a potentially tridentate ligand for a wide range of metals.

Reactions of P,SAs with group 10 metal dihalides occurred with cleavage of the As-S bond and coordination of the resulting PS ligand. However, reactions with $\left[\mathrm{MX}_{2}(\operatorname{cod})\right]$ $(\mathrm{M}=\mathrm{Pd}, \mathrm{X}=\mathrm{Cl} ; \mathrm{M}=\mathrm{Pt}, \mathrm{X}=\mathrm{I})$ led to trinuclear complexes $\left[\left(c i s-\mathrm{M}\left\{\left(\mu-S-\mathrm{SC}_{6} \mathrm{H}_{4}-2-\right.\right.\right.\right.$ $\left.\left.\left.\mathrm{PPh}_{2}\right)-\kappa^{2} S, P\right\}_{2}\right)-\mathrm{MX}_{2}-\mathrm{MX}\left\{\left(\mu-S-\mathrm{SC}_{6} \mathrm{H}_{4}-2-\mathrm{PPh}_{2}\right)-\right.$ $\left.\left.\kappa^{2} S, P\right\}\right]$ as the kinetic products, followed by formation of the thermodynamic products
$\left[\mathrm{MX}\left\{\left(\mu-S-\mathrm{SC}_{6} \mathrm{H}_{4}-2-\mathrm{PPh}_{2}\right)-\kappa^{2} S, P\right\}\right]_{3} \quad$ (Scheme 28). The isomerisation process was observed by ${ }^{31} \mathrm{P}\left\{{ }^{1} \mathrm{H}\right\}$ NMR spectroscopy; all the structural isomers were isolated and characterised by $\mathrm{X}$-ray structure analysis. In contrast, the reaction of P,SAs with $\mathrm{NiCl}_{2} \cdot 6 \mathrm{H}_{2} \mathrm{O}$ led only to the bis-chelate complex, trans-[Ni $\{(\mathbf{P S})$ $\left.\left.\kappa^{2} S, P\right\}_{2}\right][142]$.

Theoretical calculations on P,SAs predicted that the P,S chelating pocket will be favoured over the As,S unit during an electrophilic attack, which is in agreement with the previously reported experimental results. The lability of the As-S bond is suggested by the electronic structure of P,SAs and the bond dissociation energies. The observed trinuclearto-trimeric interconversions might be facilitated by intramolecular HOMO-LUMO interactions in the trinuclear isomers. Furthermore, the nature of the metal halide strongly influences the electronic structure of the trinuclear species and the progress of the isomerisation reactions [143].

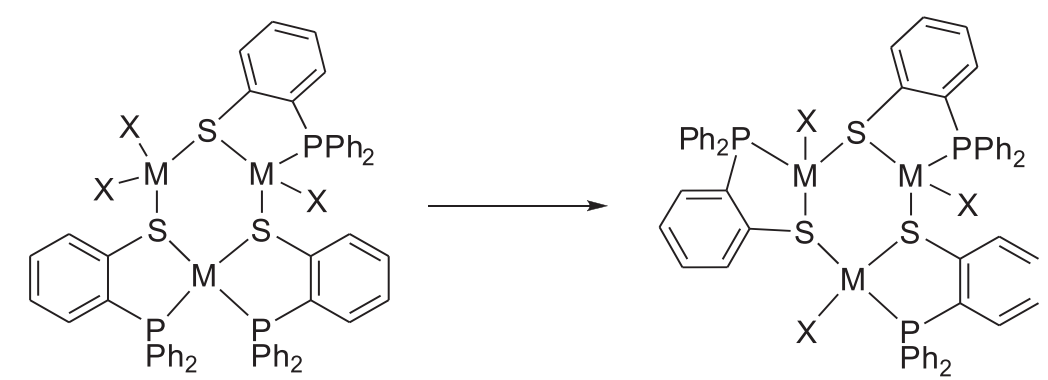

Scheme 28. Isomerisation of $\left[\left(c i s-\mathrm{M}\left\{\left(\mu-S-\mathrm{SC}_{6} \mathrm{H}_{4}-2-\mathrm{PPh}_{2}\right)-\kappa^{2} S, P\right\}_{2}\right)-\mathrm{MX}_{2}-\mathrm{MX}\left\{\left(\mu-S-\mathrm{SC}_{6} \mathrm{H}_{4}-\right.\right.\right.$ 2- $\left.\left.\left.\mathrm{PPh}_{2}\right)-\kappa^{2} S, P\right\}\right]$ to $\left[\mathrm{MX}\left\{\left(\mu-S-\mathrm{SC}_{6} \mathrm{H}_{4}-2-\mathrm{PPh}_{2}\right)-\kappa^{2} S, P\right\}\right]_{3}$

\section{REFERENCES}

[1] P. Braunstein, F. Naud, Hemilability of hybrid ligands and the coordination chemistry of oxazolinebased systems, Angew. Chem. Int. Ed., 40, 680-699 (2001); P. Braunstein, F. Naud, Hemilabilität von hybridliganden und die koordinationschemie von oxazolinliganden, Angew. Chem., 113, 702-722 (2001).
[2] C. S. Slone, D. A. Weinberger, C. A. Mirkin, The transition metal coordination chemistry of hemilabile ligands, in: Prog. Inorg. Chem., John Wiley \& Sons, Inc., 2007, pp. 233-350.

[3] M. Bassetti, Kinetic Evaluation of ligand hemilability in transition metal complexes, Eur. J. Inorg. Chem., 4473-4482 (2006).

[4] A. Bader, E. Lindner, Coordination chemistry and catalysis with hemilabile oxygen-phosphorus ligands, Coord. Chem. Rev., 108, 27-110 (1991). 
[5] J. R. Dilworth, N. Wheatley, The preparation and coordination chemistry of phosphorus-sulfur donor ligands, Coord. Chem. Rev., 199, 89-158 (2000).

[6] J. J. Schneider, Hemilabile liganden in katalyse und komplexchemie, Nachr. Chem., 48, 614-620 (2000).

[7] K. N. Gavrilov, A. I. Polosukhin, Chiral P,N-bidentate ligands in coordination chemistry and organic catalysis involving rhodium and palladium, Russian Chemical Reviews, 69, 661-682 (2000).

[8] G. Delapierre, G. Buono, P,N chiral ligands: Diversity and new advances, Actual. Chim., 3-11 (2003).

[9] J. C. Jeffrey, T. B. Rauchfuss, Metal complexes of hemilabile ligands. Reactivity and structure of dichlorobis(o-(diphenylphosphino)anisole)ruthenium(II), Inorg. Chem., 18, 2658-2666 (1979).

[10] P. Braunstein, D. Matt, F. Mathey, D. Thavard, Functional phosphines: a new synthesis of diphenylphosphinoacetonitrile and ethyl diphenylphosphinoacetate; some of their complexes with iron(0), gold(I), nickel(II), palladium(II), platinum(II), rhodium(III), and iridium(III). Stereodynamic behavior, J. Chem. Res. (S), 232-233 (1978).

[11] P. Braunstein, D. Matt, F. Mathey, D. Thavard, Functional phosphines: a new synthesis of diphenylphosphinoacetonitrile and ethyl diphenylphosphinoacetate; some of their complexes with iron( 0$)$, gold(I), nickel(II), palladium(II), platinum(II), rhodium(III), and iridium(III). Stereodynamic behavior, J. Chem. Res. (M), 3041 (1978).

[12] P. Braunstein, Functional ligands and complexes for new structures, homogeneous catalysts and nanomaterials, J. Organomet. Chem., 689, 3953-3967 (2004).

[13] P. Braunstein, M. Knorr, C. Stern, Bimetallic silicon chemistry: New opportunities in coordination and organometallic chemistry, Coord. Chem. Rev., 178-180, Part 2, 903-965 (1998).

[14] N. Lugan, F. Laurent, G. Lavigne, T. P. Newcomb, E.W. Liimatta, J. J. Bonnet, Nucleophilic activation of triruthenium carbonyl complexes by semi-labile ancillary ligands. Cluster assisted codimerization of alkynes and ethylene to give 1,2-disubstituted-1,3butadienes, J. Am. Chem. Soc., 112, 8607-8609 (1990).

[15] N. Lugan, F. Laurent, G. Lavigne, T. P. Newcomb, E. W. Liimatta, J. J. Bonnet, Activation of triruthenium carbonyl complexes by incorporation of hemilabile ancillary ligands containing alkoxo, amido, or thiolato groups. Generation of a reactive alkenyl complex, Organometallics, 11, 1351-1363 (1992).
[16] M. Yuki, Y. Miyake, Y. Nishibayashi, Preparation of thiolate-bridged dinuclear ruthenium complexes bearing a phosphine ligand and application to propargylic reduction of propargylic alcohols with 2-propanol, Organometallics, 29, 5994-6001 (2010).

[17] L.-P. He, M. Hong, B.-X. Li, J.-Y. Liu, Y.-S. Li, Ethylene/hexene living copolymerization and ethylene/methyl 10-undecenoate copolymerization by titanium complexes bearing phenoxy-phosphine or thiophenoxy-phosphine ligands, Polymer, 51, 43364339 (2010).

[18] P. Fernández, A. Sousa-Pedrares, J. Romero, M. L. Durán, A. Sousa, P. Pérez-Lourido, J. A. GarcíaVázquez, Synthesis and structural characterization of cobalt, nickel and copper phosphanylthiolato complexes, Eur. J. Inorg. Chem., 2010, 814-823 (2010).

[19] S. Ye, F. Neese, A. Ozarowski, D. Smirnov, J. Krzystek, J. Telser, J.-H. Liao, C.-H. Hung, W.-C. Chu, Y.-F. Tsai, R.-C. Wang, K.-Y. Chen, H.-F. Hsu, Family of V(III)-tristhiolato complexes relevant to functional models of vanadium nitrogenase: synthesis and electronic structure investigations by means of high-frequency and -field electron paramagnetic resonance coupled to quantum chemical computations, Inorg. Chem., 49, 977-988 (2009).

[20] A.-M. Vălean, S. Gomez-Ruiz, P. Lönnecke, I. Silaghi-Dumitrescu, L. Silaghi-Dumitrescu, E. HeyHawkins, Stabilisation of an inorganic digallane by the phosphinobisthiolato $\mathrm{P}, \mathrm{S}, \mathrm{S}$ pincer ligand $\mathrm{PPh}(2-$ $\left.\mathrm{SC}_{6} \mathrm{H}_{4}\right)_{2}$, New J. Chem., 33, 1771-1779 (2009).।

[21] P. B. Kraikivskii, M. Frey, H. A. Bennour, A. Gembus, R. Hauptmann, I. Svoboda, H. Fuess, V. V. Saraev, H.-F. Klein, Syntheses and properties of molecular nickel(II) hydride, methyl, and nickel(I) complexes supported by trimethylphosphane and (2-diphenylphosphanyl)thiophenolato and -naphtholato ligands, J. Organomet. Chem., 694, 1869-1876 (2009).

[22] A. M. Vălean, S. Gómez-Ruiz, P. Lönnecke, I. Silaghi-Dumitrescu, L. Silaghi-Dumitrescu, E. HeyHawkins, When arsine makes the difference: chelating phosphino- and bridging arsinoarylthiolato gallium complexes, Inorg. Chem., 47, 11284-11293 (2008).

[23] T. W. Chiou, W.-F. Liaw, Mononuclear nickel(III) complexes $\left[\mathrm{Ni}^{\mathrm{III}}(\mathrm{OR})\left(\mathrm{P}\left(\mathrm{C}_{6} \mathrm{H}_{3}-3-\mathrm{SiMe}_{3}-2-\mathrm{S}\right)_{3}\right)\right]^{-}(\mathrm{R}$ $=\mathrm{Me}, \mathrm{Ph}$ ) containing the terminal alkoxide ligand: relevance to the nickel site of oxidized-form [NiFe] hydrogenases, Inorg. Chem., 47, 7908-7913 (2008). 
[24] V. Gómez-Benítez, R. A. Toscano, D. MoralesMorales, Synthesis and characterization of $\left[\mathrm{Pd}\left\{\mathrm{PhP}\left(\mathrm{C}_{6} \mathrm{H}_{4}-2-\mathrm{SCH}_{2} \mathrm{Cl}\right)\left(\mathrm{C}_{6} \mathrm{H}_{4}-2-\mathrm{S}\right)\right\}\left(\mathrm{Ph}_{2}\right.\right.$ $\left.\left.\mathrm{PCH}_{2} \mathrm{CH}_{2} \mathrm{PPh}_{2}\right)\right] \mathrm{Cl}$ : An example of hemilability and dichloromethane activation, Inorg. Chem. Commun., 10, 1-6 (2007).

[25] L. She, X. Li, H. Sun, J. Ding, M. Frey, H.-F. Klein, Insertion of alkynes into $\mathrm{Ni}-\mathrm{H}$ bonds: synthesis of novel vinyl nickel(II) and dinuclear vinyl nickel(II) complexes containing a [P, S]-ligand, Organometallics, 26, 566-570 (2007).

[26] C. M. Lee, Y. L. Chuang, C. Y. Chiang, G. H. Lee, W. F. Liaw, Mononuclear Ni(III) complexes [ $\left[\mathrm{Ni}^{\mathrm{III}}(\mathrm{L})\right.$ $\left.\left.\left(\mathrm{P}_{2} \mathrm{C}_{6} \mathrm{H}_{3}-3-\mathrm{SiMe}_{3}-2-\mathrm{S}\right)_{3}\right)\right]^{0 / 1-}(\mathrm{L}=$ thiolate, selenolate, $\mathrm{CH}_{2} \mathrm{CN}, \mathrm{Cl}, \mathrm{PPh}_{3}$ ): relevance to the nickel site of [NiFe] hydrogenases, Inorg. Chem., 45, 1089510904 (2006).

[27] W. C. Chu, C. C. Wu, H. F. Hsu, Catalytic reduction of hydrazine to ammonia by a vanadium thiolate complex, Inorg. Chem., 45, 3164-3166 (2006).

[28] M. Gorol, H. W. Roesky, M. Noltemeyer, H.-G. Schmidt, $\quad\left(\eta^{5}\right.$-Pentamethylcyclopentadienyl)iridium(III) complexes with $\eta^{2}-\mathrm{N}, \mathrm{O}$ and $\eta^{2}$-P,S ligands, Eur. J. Inorg. Chem., 4840-4844 (2005).

[29] J. A. Cabeza, M. A. Martínez-García, V. Riera, D. Ardura, S. García-Granda, Reactivity of 2-(diphenylphosphanyl)thiophenol $\left(\mathrm{HSC}_{6} \mathrm{H}_{4} \mathrm{PPh}_{2}\right)$ with ruthenium and osmium carbonyl complexes; breaking of $\mathrm{HSC}_{6} \mathrm{H}_{4} \mathrm{PPh}_{2}$ into sulfide, phenyl and diphenylphosphanyl ligands on a triruthenium cluster, Eur. J. Inorg. Chem., 2000, 499-503 (2000).

[30] J. Mason, Multinuclear NMR, Springer US, 1987.

[31] S. B. Wild, Optically active arsines: preparation, uses and chiroptical properties, in: Organic arsenic, antimony and bismuth compounds (1994), John Wiley \& Sons, Ltd, 2004, pp. 89-152.

[32] V. Farina, B. Krishnan, Large rate accelerations in the Stille reaction with tri-2-furylphosphine and triphenylarsine as palladium ligands: mechanistic and synthetic implications, J. Am. Chem. Soc., 113, 9585-9595 (1991).

[33] C. Amatore, A. A. Bahsoun, A. Jutand, G. Meyer, N. Ndedi, L. Ricard, Mechanism of the Stille reaction catalyzed by palladium ligated to arsine ligand: $\mathrm{PhPdI}\left(\mathrm{AsPh}_{3}\right)(\mathrm{DMF})$ is the species reacting with vinylstannane in DMF, J. Am. Chem. Soc., 125, 42124222 (2003).

[34] C. R. Johnson, M. P. Braun, A two-step, three-component synthesis of PGE1: utilization of $\alpha$-iodoenones in $\mathrm{Pd}(0)$-catalyzed cross-couplings of organoboranes, J. Am. Chem. Soc., 115, 11014-11015 (1993).
[35] R. B. Bedford, C. S. J. Cazin, S. J. Coles, T. Gelbrich, M.B. Hursthouse, V. J. M. Scordia, Phosphine and arsine adducts of N-donor palladacycles as catalysts in the Suzuki coupling of aryl bromides, Dalton Trans., 3350-3356 (2003).

[36] L. A. van der Veen, P. K. Keeven, P. C. J. Kamer, P. W. N. M. van Leeuwen, Novel arsine ligands for selective hydroformylation of alk-1-enes employing platinum/tin catalysts, Chem. Commun., 333-334 (2000).

[37] R. A. Baber, S. Collard, M. Hooper, A. G. Orpen, P. G. Pringle, M. J. Wilkinson, R. L. Wingad, Bulky triarylarsines are effective ligands for palladium catalysed Heck olefination, Dalton Trans., 1491-1498 (2005).

[38] S. Ceccarelli, U. Piarulli, C. Gennari, Effect of ligands and additives on the palladium-promoted carbonylative coupling of vinyl stannanes and electronpoor enol triflates, J. Org. Chem., 65, 6254-6256 (2000).

[39] W. M. Dai, A. Wu, H. Wu, Asymmetric Wittig reactions of chiral arsonium ylides. Part 3: Reversal of stereochemistry caused by metal cation in enantioselective olefination of 4-substituted cyclohexanones using a $C_{2}$-symmetric chiral arsine, Tetrahedron: Asymmetry, 13, 2187-2191 (2002).

[40] E. S. Raper, Complexes of heterocyclic thione donors, Coord. Chem. Rev., 61, 115-184 (1985).

[41] P. J. Blower, J. R. Dilworth, Thiolato-complexes of the transition metals, Coord. Chem. Rev., 76, 121185 (1987).

[42] E. S. Raper, Complexes of heterocyclic thionates. Part 1. Complexes of monodentate and chelating ligands, Coord. Chem. Rev., 153, 199-255 (1996).

[43] E. S. Raper, Complexes of heterocyclic thionates Part 2: Complexes of bridging ligands, Coord. Chem. Rev., 165, 475-567 (1997).

[44] H. Fritzsche, U. Hasserodt, F. Korte, A new method for the formation of P-P bonds, Angew. Chem., Int. Ed., 3, 64-64 (1964); H. Fritzsche, U. Hasserodt, F. Korte, Weiteres verfahren zur knüpfung von P-Pbindungen, Angew. Chem., 75, 1205-1205 (1963).

[45] R. Fusco, C. A. Peri, V. Corradini, Sulfur-containing arsenical fungicides, Montecatini, Patent: BE621008, (1963).

[46] B. E. Job, R. A. N. McLean, D. T. Thompson, Binuclear metal carbonyls having both phosphorus and sulphur bridges, Chem. Commun. (London), 895896 (1966). 
[47] R. A. N. McLean, Phenylthio- and phenylselenodiphenyl phosphine, Inorg. Nucl. Chem. Lett., 5, 745-747 (1969).

[48] S. C. Peake, R. Schmutzler, Phosphorus-fluorine chemistry. Part XXII. Alkylthio- and arylthio-substituted fluorophosphoranes, J. Chem. Soc. A, 10491054 (1970).

[49] L. Horner, M. Jordan, Phosphororganische verbindungen 90, Phosphorus Sulfur, 8, 215-219 (1980).

[50] C. D. Hall, B. R. Tweedy, R. Kayhanian, J. R. Lloyd, The kinetics and mechanism of the reaction of tricoordinate phosphorus compounds with diaryl trisulfides, J. Chem. Soc., Perk. Trans. 2, 775-779 (1992).

[51] V. Cadierno, M. Zablocka, B. Donnadieu, A. Igau, J.-P. Majoral, A. Skowronska, $\mathrm{X}-\mathrm{H}(\mathrm{X}=\mathrm{C}, \mathrm{N}, \mathrm{O}, \mathrm{P}$, $\mathrm{S})$ Bond activations induced by $\beta$-heterosubstituted zirconaindenes, Chem. Eur. J., 7, 221-229 (2001).

[52] L. B. Han, T. D. Tilley, Selective homo- and heterodehydrocouplings of phosphines catalyzed by rhodium phosphido complexes, J. Am. Chem. Soc., 128, 13698-13699 (2006).

[53] T. D. Sideris, P. V. Ioannou, Studies on the air oxidation of some arsenic(III) compounds, Phosphorus Sulfur, 181, 751-762 (2006).

[54] R. M. Bozorth, The crystal structures of the cubic forms of arsenious and antimonous oxides, J. Am. Chem. Soc., 45, 1621-1627 (1923).

[55] J. Kopf, K. Von Deuten, G. Klar, Crystal and molecule structure of 1,3,5,7-tetraarsa-2,4,6,8-tetraoxaadamantane, Inorg. Chim. Acta, 38, 67-69 (1980).

[56] B. J. McKerley, K. Reinhardt, J. L. Mills, G. M. Reisner, J. D. Korp, I. Bernal, Synthesis and structure of an organocyclotriarsinetrioxide, Inorg. Chim. Acta, 31, L411-L412 (1978).

[57] I. Bernal, H. Brunner, W. Meier, H. Pfisterer, J. Wachter, M. L. Ziegler, Ligand extrusion from the $\mathrm{As}_{4} \mathrm{~S}_{4}$-cage by $\left[\mathrm{C}_{5} \mathrm{Me}_{5}(\mathrm{CO})_{2} \mathrm{Mo}\right]_{2}$ : formation of $\left(\mathrm{C}_{5} \mathrm{Me}_{5}\right)_{2} \mathrm{Mo}_{2}(\mathrm{CO})_{4}\left(\mu, \eta^{2}-\mathrm{As}_{2}\right), \quad \mathrm{C}_{5} \mathrm{Me}_{5}(\mathrm{CO})_{2} \mathrm{Mo}\left(\eta^{3}-\right.$ $\left.\mathrm{As}_{3}\right)$, and $\left(\mathrm{C}_{5} \mathrm{Me}_{5}\right)_{2} \mathrm{Mo}_{2} \mathrm{As}_{2} \mathrm{~S}_{3}$, Angew. Chem., Int. Ed., 23, 438-439 (1984); I. Bernal, H. Brunner, W. Meier, H. Pfisterer, J. Wachter, M. L. Ziegler, Ligandenerzeugung aus dem $\mathrm{As}_{4} \mathrm{~S}_{4}-$ käfig durch $\left[\mathrm{C}_{5} \mathrm{Me}_{5}(\mathrm{CO})_{2} \mathrm{Mo}\right]_{2}$ : bildung von $\left(\mathrm{C}_{5} \mathrm{Me}_{5}\right)_{2} \mathrm{Mo}_{2}(\mathrm{CO})_{4}\left(\mu, \eta^{2}-\mathrm{As}_{2}\right), \quad \mathrm{C}_{5} \mathrm{Me}_{5}(\mathrm{CO})_{2} \mathrm{Mo}\left(\eta^{3}-\right.$ $\left.\mathrm{As}_{3}\right)$ und $\left(\mathrm{C}_{5} \mathrm{Me}_{5}\right)_{2} \mathrm{Mo}_{2} \mathrm{As}_{2} \mathrm{~S}_{3}$, Angew. Chem., 96, 428-429 (1984).

[58] H. Brunner, H. Kauermann, B. Nuber, J. Wachter, M. L. Ziegler, Complex-induced fragmentation of $\mathrm{As}_{4} \mathrm{~S}_{4}$ : stabilization of an $\mathrm{As}_{2} \mathrm{~S}_{3}$ ligand, Angew. Chem., Int. Ed., 25, 557-558 (1986); H. Brunner, H. Kauermann, B. Nuber, J. Wachter, M. L. Ziegler,
Komplexinduzierter abbau von $\mathrm{As}_{4} \mathrm{~S}_{4}$ : stabilisierung eines $\mathrm{As}_{2} \mathrm{~S}_{3}$-liganden, Angew. Chem., 98, 551-552 (1986).

[59] H. Brunner, L. Poll, J. Wachter, B. Nuber, New As-S Cage structures with organometallic components formed by complex-induced realgar fragmentation, Angew. Chem., Int. Ed., 32, 1627-1628 (1993); H. Brunner, B. Nuber, L. Poll, J. Wachter, Neue As-Skäfigstrukturen mit metallorganischen komponenten durch komplexinduzierten realgar-abbau, Angew. Chem., 105, 1699-1701 (1993).

[60] H. Brunner, L. Poll, J. Wachter, B. Nuber, Neue FeAsS-käfigstrukturen aus $\left[\mathrm{Cp}^{+} \mathrm{Fe}(\mathrm{CO})_{2}\right]_{2}\left(\mathrm{Cp}^{+}=\right.$ $\left.\mathrm{C}_{5} \mathrm{Me}_{4} \mathrm{Et}\right)$ und realgar, J. Organomet. Chem., 471, 117-122 (1994).

[61] H. Brunner, L. Poll, J. Wachter, New insights into the cage fragmentation of $\mathrm{As}_{4} \mathrm{~S}_{4}$ and $\mathrm{As}_{4} \mathrm{~S}_{3}$ by their interaction with $\left(\mathrm{C}_{5} \mathrm{Me}_{4} \mathrm{Et}\right)_{2} \mathrm{Fe}_{2}(\mathrm{CO})_{4}$, Polyhedron, 15, 573-576 (1996).

[62] H. Brunner, H. Kauermann, L. Poll, B. Nuber, J. Wachter, The reaction of $\mathrm{As}_{4} \mathrm{Sn}(\mathrm{n}=3,4)$ and $\mathrm{As}_{2} \mathrm{~S}_{3}$ with $\left(\mathrm{C}_{5} \mathrm{Me}_{4} \mathrm{R}\right)_{2} \mathrm{Co}_{2}(\mathrm{CO})_{2}(\mathrm{R}=\mathrm{Me}, \mathrm{Et})$ : fragmentation and reassembling of main-group ligands by organometallic complexes, Chem. Ber., 129, 657-662 (1996).

[63] G. Le Borgne, R. Mathieu, Structural study of iron carbonyl derivatives V. Synthesis and crystal and molecular structure of $\mu-\left(\mathrm{SC}_{6} \mathrm{H}_{5}\right)-\mu-\left(\mathrm{P}_{2}\left(\mathrm{C}_{6} \mathrm{H}_{5}\right)_{2}\right)$ $\mathrm{Fe}_{2}(\mathrm{CO})_{6}$, J. Organomet. Chem., 208, 201-212 (1981).

[64] G. Conole, J. E. Davies, J. D. King, M. J. Mays, M. McPartlin, H. R. Powell, P. R. Raithby, Reactions of thioarsines with metal carbonyls: synthesis and structural characterisation of $\left[\mathrm{Fe}_{2}(\mathrm{CO})_{6}(\mu-\right.$ $\left.\left.\mathrm{AsMe}_{2}\right)(\mu-\mathrm{SPh})\right], \quad\left[\mathrm{Fe}_{2} \mathrm{Cp}_{2}(\mathrm{CO})_{2}\left(\mu-\mathrm{AsPh}_{2}\right)(\mu-\mathrm{SPh})\right]$, $\left[\mathrm{Mn}_{2}(\mathrm{CO})_{8}\left(\mu-\mathrm{AsPh}_{2}\right)(\mu-\mathrm{SPh})\right]$ and $\left[\mathrm{Co}_{3}\left(\mu_{3}-\mathrm{S}\right)\right.$ $\left.\left(\mu-\mathrm{AsPh}_{2}\right)(\mathrm{CO})_{6} \mathrm{AsPh}_{3}\right]$, J. Organomet. Chem., 585, 141-149 (1999).

[65] J. A. Adeleke, Y. W. Chen, L. K. Liu, Preparation and crystal structures of iron complexes syn-[( $\mu$ $\left.\mathrm{SPh}) \mathrm{Fe}(\mathrm{CO})_{3}\right]_{2},\left(\mathrm{C}_{5} \mathrm{H}_{4} \mathrm{SPh}\right)_{2} \mathrm{Fe},\left(\mathrm{C}_{5} \mathrm{H}_{5}\right) \mathrm{Fe}\left(\mathrm{C}_{5} \mathrm{H}_{4} \mathrm{SPh}\right)$, and $\left(\mathrm{C}_{5} \mathrm{H}_{4} \mathrm{SPh}\right) \mathrm{Fe}\left(\mathrm{C}_{5} \mathrm{H}_{4} \mathrm{PPh}_{2}\right)$, Organometallics, 11, 2543-2550 (1992).

[66] A. J. Edwards, A. Martin, M. J. Mays, P. R. Raithby, G. A. Solan, Interchange of $\mathrm{SPh}$ and $\mathrm{PPh}_{2}$ groups at a dicobalt centre: crystal and molecular structures of $\left[\mathrm{Co}_{2}\left(\mu-\mathrm{PPh}_{2}\right)\{\mu-\mathrm{SPhC}(\mathrm{O}) \mathrm{CHCH}\}(\mathrm{CO})_{4}\right]$ and $\left[\mathrm{Co}_{2}(\mu-\right.$ $\left.\mathrm{SPh})\left\{\mu-\mathrm{PPh}_{2} \mathrm{CHCHC}(\mathrm{O})\right\}(\mathrm{CO})_{2}\left\{\mathrm{P}(\mathrm{OMe})_{3}\right\}_{2}\right], \quad J$. Chem. Soc., Chem. Commun., 1416-1418 (1992).

[67] G. Conole, M. Kessler, M. J. Mays, G. E. Pateman, G. A. Solan, Labile SR'C(O)CRCH-bridged dicobalt 
complexes; synthesis, structures ${ }^{13} \mathrm{CO}$ labelling studies, Polyhedron, 17, 2993-3004 (1998).

[68] A. J. Edwards, A. Martian, M. J. Mays, D. Nazar, P. R. Raithby, G. A. Solan, Synthesis and reactions with alkynes of complexes containing both phosphorus and sulfur bridging ligands: crystal and molecular structures of $\left[\mathrm{Mn}_{2}\left(\mu-\mathrm{PPh}_{2}\right)(\mu-\mathrm{SPh})(\mathrm{CO})_{8}\right]$, $\left[\mathrm{Co}_{3}\left(\mu_{3}-\mathrm{S}\right)\left(\mu-\mathrm{PPh}_{2}\right)(\mathrm{CO})_{6}\left(\mathrm{PPh}_{3}\right)\right]$ and $\left[\mathrm{Co}_{3}\left(\mu_{3}-\mathrm{S}\right)\right.$ $\left.\left(\mu-\mathrm{PPh}_{2} \mathrm{CHCPh}\right)(\mathrm{CO})_{6}\left(\mathrm{PPh}_{3}\right)\right]$, J. Chem. Soc., Dalton Trans., 355-363 (1993).

[69] A. Martin, M. J. Mays, P. R. Raithby, G. A. Solan, Reactions of the heteronuclear alkyne-bridged cobalt-molybdenum complex $\quad\left[(\mathrm{OC})_{3} \mathrm{Co}\{\mu-\right.$ $\left.\left.\mathrm{C}_{2}\left(\mathrm{CO}_{2} \mathrm{Me}\right)_{2}\right\} \mathrm{Mo}(\mathrm{CO})_{2}\left(\eta^{5}-\mathrm{C}_{5} \mathrm{H}_{5}\right)\right]$ with $\mathrm{PPh}_{2} \mathrm{H}, \mathrm{P}_{2} \mathrm{Ph}_{4}$ and $\mathrm{PPh}_{2}(\mathrm{SPh})$, J. Chem. Soc., Dalton Trans., 14311439 (1993).

[70] S. L. Ingham, M. J. Mays, P. R. Raithby, G. A. Solan, B. V. Sundavadra, G. Conole, M. Kessler, Phosphorus-sulfur bond cleavage at a mixed-metal centre; reaction of $\left[(\mathrm{OC})_{3} \mathrm{Co}(\mu-\mathrm{PHCCH}) \mathrm{Mo}(\mathrm{CO})_{2}\left(\eta^{5}-\mathrm{C}_{5} \mathrm{H}_{5}\right)\right]$ with $\mathrm{PPh}_{2}(\mathrm{SPh})$, J. Chem. Soc., Dalton Trans., 3607-3614 (1994).

[71] J. D. King, M. J. Mays, G. E. Pateman, P. R. Raithby, M. A. Rennie, G. A. Solan, N. Choi, G. Conole, M. McPartlin, The formation and transformation of metallacycles containing phosphorus or sulfur on molybdenum- or tungsten-cobalt mixed-metal backbones, J. Chem. Soc., Dalton Trans., 4447-4456 (1999).

[72] E. Block, G. Ofori-Okai, J. Zubieta, 2-Phosphinoand 2-phosphinylbenzenethiols: new ligand types, $J$. Am. Chem. Soc., 111, 2327-2329 (1989).

[73] A. Hildebrand, I. Sárosi, P. Lönnecke, L. SilaghiDumitrescu, M. B. Sárosi, I. Silaghi-Dumitrescu, E. Hey-Hawkins, Heteropolytopic arsanylarylthiolato ligands: cis-trans isomerism of nickel(II), palladium(II), and platinum(II) complexes of 1- $\mathrm{AsPh}_{2}-2-\mathrm{SHC}_{6} \mathrm{H}_{4}$, Inorg. Chem., 51, 7125-7133 (2012).

[74] S. E. Livingstone, T. N. Lockyer, Metal complexes of two new sulphur-phosphorus chelating agents, Inorg. Nucl. Chem. Lett., 3, 35-38 (1967).

[75] G. D. Figuly, C. K. Loop, J. C. Martin, Directed ortho-lithiation of lithium thiophenolate. New methodology for the preparation of ortho-substituted thiophenols and related compounds, J. Am. Chem. Soc., 111, 654-658 (1989).

[76] E. Block, V. Eswarakrishnan, M. Gernon, G. OforiOkai, C. Saha, K. Tang, J. Zubieta, o-Lithiothiophenol equivalents. Generation, reactions and applications in synthesis of hindered thiolate ligands, J. Am. Chem. Soc., 111, 658-665 (1989).
[77] K. Smith, C. M. Lindsay, G. J. Pritchard, Directed lithiation of arenethiols, J. Am. Chem. Soc., 111, 665-669 (1989).

[78] P. Beak, R. A. Brown, The tertiary amide as an effective director of ortho lithiation, J. Org. Chem., 47, 34-46 (1982).

[79] P. Beak, V. Snieckus, Directed lithiation of aromatic tertiary amides: an evolving synthetic methodology for polysubstituted aromatics, Acc. Chem. Res., 15, 306-312 (1982).

[80] V. Snieckus, Directed ortho metalation. Tertiary amide and $\mathrm{O}$-carbamate directors in synthetic strategies for polysubstituted aromatics, Chem. Rev., 90, 879-933 (1990).

[81] C. G. Hartung, V. Snieckus, The directed ortho metalation reaction - a point of departure for new synthetic aromatic chemistry, in: Modern arene chemistry, D. Astruc (Ed.), Wiley-VCH Verlag GmbH \& Co. KGaA, 2004, pp. 330-367.

[82] A. Wheatley, The directed lithiation of benzenoid aromatic systems, Eur. J. Inorg. Chem., 2003, 32913303 (2003).

[83] B. J. Wakefield, The chemistry of organolithium compounds, Pergamon, Oxford, UK, 1974.

[84] M. Gray, M. Tinkl, V. Sniekus, Lithium, in: Comprehensive organometallic chemistry II, G. Wilkinson, F. G. A. Stone, E. Abel (Eds.), Pergamon, Oxford, UK, 1991.

[85] A. Streitwieser, Carbanion ion pairs and triplets, Acc. Chem. Res., 17, 353-357 (1984).

[86] D. Kost, J. Klein, A. Streitwieser, G. W. Schriver, Ab initio calculations of dilithiopropenes, Proc. Natl. Acad. Sci. U.S.A., 79, 3922-3926 (1982).

[87] A. Hildebrand, P. Lönnecke, I. Silaghi-Dumitrescu, L. Silaghi-Dumitrescu, E. Hey-Hawkins, Co-complexes of ortho-dilithiated thiophenol or 2-trimethylsilylthiophenol with lithiated TMEDA molecules: synthesis, crystal structures and theoretical studies $($ TMEDA $=$ N,N,N',N'-tetramethylethylenediamine), Dalton Trans., 967-974 (2006).

[88] S. E. Livingstone, 858. Metallic complexes of dimethyl-o-methylthiophenylarsine. Part I. Complexes of nickel and palladium, J. Chem. Soc., 42224226 (1958).

[89] B. Chiswell, S. E. Livingstone, 219. Metallic complexes of dimethyl-o-(methylthio)phenylarsine. Part IV. Complexes of platinum, J. Chem. Soc., 10711074 (1960).

[90] N. C. Stephenson, The crystal structure of di-iododi-(o-phenylenebisdimethylarsine) platinum(II) 
$\mathrm{Pt}\left(\mathrm{C}_{6} \mathrm{H}_{4}\left[\mathrm{As}\left(\mathrm{CH}_{3}\right)_{2}\right]_{2}\right)_{2} \mathrm{I}_{2}$, J. Inorg. Nucl. Chem., 24, 791-795 (1962).

[91] V. F. Duckworth, N. C. Stephenson, Crystal structure of diiodobis(o-phenylenebis(dimethylarsine)) gold(III) iodide - a discrete six-coordinate cationic complex of gold(III), Inorg. Chem., 8, 1661-1664 (1969).

[92] J. P. Beale, N. C. Stephenson, The crystal and molecular structure of diiodobis(dimethyl-o-methylthiophenylarsine)palladium(II), Acta Cryst. B, 26, 1655-1661 (1970).

[93] J. P. Beale, N. C. Stephenson, The crystal and molecular structure of bis(dimethyl-o-thiolophenylarsine) platinum(II), Acta Cryst. B, 27, 73-80 (1971).

[94] E. M. Miller, B. L. Shaw, Kinetic and other studies on oxidative addition reactions of iridium phosphine complexes of the type trans-[ $\left.\mathrm{IrCl}(\mathrm{CO})\left(\mathrm{PMe}_{2} \mathrm{R}\right)_{2}\right]$ $\left(\mathrm{R}=\mathrm{Ph}, o-\mathrm{MeO} \cdot \mathrm{C}_{6} \mathrm{H}_{4}\right.$, or $\left.p-\mathrm{MeO} \cdot \mathrm{C}_{6} \mathrm{H}_{4}\right), J$. Chem. Soc., Dalton Trans., 480-485 (1974).

[95] L. F. Lindoy, S. E. Livingstone, T. N. Lockyer, Sdealkylation and S-alkylation reactions of metal chelates of sulfur ligands, Inorg. Chem., 6, 652-656 (1967).

[96] G. Dyer, M. O. Workman, D. W. Meek, Palladium(II) complexes with polydentate phosphorus-sulfur ligands, Inorg. Chem., 6, 1404-1407 (1967).

[97] L. Lindoy, S. Livingstone, T. Lockyer, Sulphurnitrogen chelating agents. IV. Metal complexes of o-methylthioaniline, Aust. J. Chem., 20, 471-478 (1967).

[98] T. Lockyer, S-dealkylation reactions of palladium(II) complexes of some phosphorus-sulphur and arsenic-sulphur chelates, Aust. J. Chem., 27, 259-267 (1974).

[99] S. K. Harbron, S. J. Higgins, E. G. Hope, T. Kemmitt, W. Levason, Coordination chemistry of higher oxidation states. Part 24. Palladium(IV) and nickel(III) complexes of hybrid thio- and seleno-ether ligands, Inorg. Chim. Acta, 130, 43-47 (1987).

[100] M. G. Fitzpatrick, L. R. Hanton, W. Henderson, P. E. Kneebone, E. G. Levy, L. J. McCaffrey, D. A. McMorran, Application of electrospray mass spectrometry to the characterisation of tertiary arsine ligands, Inorg. Chim. Acta, 281, 101-110 (1998).

[101] W. S. Tsang, D. W. Meek, A. Wojcicki, Seven-coordinate carbonyl complexes of molybdenum(II) and tungsten(II), Inorg. Chem., 7, 1263-1268 (1968).

[102] E. Block, H. Kang, G. Oforiokai, J. Zubieta, Coordination chemistry of molybdenum with novel thiolate ligands. The crystal and molecular structures of a binuclear complex with a Mo-Mo triple bond $\left[\mathrm{Mo}_{2}\left(\mathrm{SC}_{6} \mathrm{H}_{4}-\mathrm{O}-\mathrm{PPh}_{2}\right)_{3} \mathrm{Cl}_{3}\right]$ and of $\left[\mathrm{Mo}\left(\mathrm{SC}_{6} \mathrm{H}_{3}-\right.\right.$ 2- $\left.\mathrm{SiMe}_{3}-6-\mathrm{P}(\mathrm{O}) \mathrm{Ph}_{2}\right)_{2} \mathrm{Cl}_{2}$ ], a species exhibiting [ $\left.\mathrm{MoO}_{2} \mathrm{~S}_{2} \mathrm{Cl}_{2}\right]$ coordination, Inorg. Chim. Acta, 166, 155-157 (1989).

[103] C. Bolzati, F. Refosco, F. Tisato, G. Bandoli, A. Dolmella, Novel $\mathrm{TcP}_{3} \mathrm{X}_{3}(\mathrm{X}=\mathrm{S}, \mathrm{O})$ cores in Tc(III) chemistry, Inorg. Chim. Acta, 201, 7-10 (1992).

[104] J. R. Dilworth, A. J. Huston, S. Morton, M. Harman, M. B. Hursthouse, J. Zubieta, C. M. Archer, J. D. Kelly, The preparation and electrochemistry of technetium and rhenium complexes of 2-(diphenylphosphino)benzenethiol. The crystal and molecular structures of $\left[\mathrm{Re}\left(2-\mathrm{Ph}_{2} \mathrm{PC}_{6} \mathrm{H}_{4} \mathrm{~S}\right)_{3}\right]$ and $[\mathrm{Tc}(2-$ $\left.\left.\mathrm{Ph}_{2} \mathrm{PC}_{6} \mathrm{H}_{4} \mathrm{~S}\right)_{3}\right]$, Polyhedron, 11, 2151-2155 (1992).

[105] C. Bolzati, A. Boschi, L. Uccelli, E. Malago, G. Bandoli, F. Tisato, F. Refosco, R. Pasqualini, A. Duatti, Synthesis of a novel class of trigonal bipyramidal nitrido $\mathrm{Tc}(\mathrm{V})$ complexes with phosphino-thiol ligands. crystal structure of $\left.{ }^{999} \mathrm{Tc}(\mathrm{N})\left(\mathrm{L}^{1}\right)_{2}\right]\left[\mathrm{L}^{1}=\right.$ 2-(diphenylphosphino)ethanethiolato] and ${ }^{999} \mathrm{Tc}(\mathrm{N})$ $\left.\left(\mathrm{L}^{5}\right)_{2}\right]\left[\mathrm{L}^{5}=2\right.$-(ditolylphosphino)propanethiolato], Inorg. Chem. 1999, 38, 4473-4479.

[106] J. R. Dilworth, D. V. Griffiths, S. J. Parrott, Y. Zheng, Synthesis and characterisation of rhenium dithiocarbamate complexes. Crystal structures of $\left[\mathrm{ReO}\left\{\mathrm{O}(\mathrm{OH}) \mathrm{C}_{6} \mathrm{H}_{4}\right\}\left(\mathrm{S}_{2} \mathrm{CNEt}\right)_{2}\right], \quad\left[\mathrm{Re}\left\{\mathrm{PPh}_{2}\left(\mathrm{C}_{6} \mathrm{H}_{4} \mathrm{~S}-\right.\right.\right.$ $\left.2)\}_{2}\left(\mathrm{~S}_{2} \mathrm{CNEt}\right)_{2}\right) \cdot \mathrm{Me}_{2} \mathrm{CO}$ and $\left[\mathrm{ReO}\left\{\mathrm{PPh}-\left(\mathrm{C}_{6} \mathrm{H}_{4} \mathrm{~S}-2\right)_{2}\right\}\right.$ $\left.\left(\mathrm{S}_{2} \mathrm{CNEt}\right)_{2}\right)$, J. Chem. Soc., Dalton Trans., 29312936 (1997).

[107] P. Pérez-Lourido, J. Romero, J. A. García-Vázquez, A. Sousa, K. P. Maresca, J. Zubieta, Synthesis and Characterization of rhenium(III) organohydrazide compounds. crystal and molecular structures of $\left[\mathrm{ReCl}\left(\mathrm{PPh}_{3}\right)_{2}\left(\mathrm{NHNC}_{5} \mathrm{H}_{4} \mathrm{~N}\right)\left(\mathrm{HNNC}_{5} \mathrm{H}_{4} \mathrm{~N}\right)\right]$ $\mathrm{Cl}_{2},\left[\operatorname{Re}\left\{2-\left(\mathrm{Ph}_{2} \mathrm{P}\right) \mathrm{C}_{6} \mathrm{H}_{4} \mathrm{~S}\right\}\left\{2-\left(\mathrm{Ph}_{2} \mathrm{PO}\right) \mathrm{C}_{6} \mathrm{H}_{4} \mathrm{~S}\right\}\right.$ $\left.\left(\mathrm{NNC}_{5} \mathrm{H}_{4} \mathrm{~N}\right)\left(\mathrm{HNNC}_{5} \mathrm{H}_{4} \mathrm{~N}\right)\right]$, and $\left[\mathrm{Re}\left\{2-\left(\mathrm{Ph}_{2} \mathrm{P}\right)\right.\right.$ $\left.\mathrm{C}_{6} \mathrm{H}_{4} \mathrm{~S}_{2}\left(\mathrm{NNC}_{5} \mathrm{H}_{4} \mathrm{~N}\right)\right]$, Inorg. Chem., 38, 15111519 (1999).

[108] P. Perez-Lourido, J. Romero, J. Garcia-Vazquez, A. Sousa, K. P. Maresca, D. J. Rose, J. Zubieta, Synthesis and characterization of rhenium phosphinothiolate complexes. crystal and molecular structures of $\left[\mathrm{HNEt}_{3}\right]\left[\mathrm{Re}\left\{\mathrm{P}\left(\mathrm{C}_{6} \mathrm{H}_{4} \mathrm{~S}\right)_{3}\right\}_{2}\right]$, $\left[\mathrm{ReOCl}\left\{\mathrm{OP}\left(\mathrm{C}_{6} \mathrm{H}_{5}\right)_{2}\left(\mathrm{C}_{6} \mathrm{H}_{4} \mathrm{~S}\right)\right\}\left\{\left(\mathrm{P}\left(\mathrm{C}_{6} \mathrm{H}_{5}\right)_{2}\left(\mathrm{C}_{6}\right.\right.\right.\right.$ -

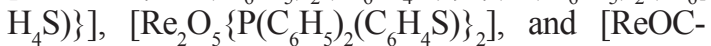
$\left.1\left\{\mathrm{OP}\left(\mathrm{C}_{6} \mathrm{H}_{5}\right)_{2}\left(2-\mathrm{SC}_{6} \mathrm{H}_{3}-3-\mathrm{SiMe}_{3}\right)\right\}_{2}\right]$, Inorg. Chem., 37, 3331-3336 (1998).

[109] P. Pérez-Lourido, J. Romero, J. A. García-Vázquez, J. Castro, A. Sousa, L. Cooper, J. R. Dilworth, R. L. Richards, Y. Zheng, J. A. Zubieta, Synthesis and characterisation of iron and cobalt complexes with phosphinothiolate ligands, Inorg. Chim. Acta, 356, 193-202 (2003). 
[110] H. F. Klein, M. Frey, S. Mao, Steering of configuration by (2-phosphanyl)phenolato ligands in trimethylphosphane iron complexes, Z. Anorg. Allg. Chem., 631, 1516-1523 (2005).

[111] J. Dilworth, Y. Zheng, S. Lu, Q. Wu, Preparation and characterization of a novel asymmetrically oxidized complex of 2-(diphenylphosphino)-benzenethiol with ruthenium. The crystal and molecular structure of $\left[\mathrm{Ru}\left(2-\mathrm{Ph}_{2} \mathrm{PC}_{6} \mathrm{H}_{4} \mathrm{~S}\right) \cdot\left(2-\mathrm{Ph}_{2} \mathrm{PC}_{6} \mathrm{H}_{4} \mathrm{~S}-\mathrm{OH}\right)\right.$ $\left.\left(2-\mathrm{Ph}_{2} \mathrm{PC}_{6} \mathrm{H}_{4} \mathrm{SO}_{2}\right)\right] \cdot 1 / 2 \mathrm{H}_{2} \mathrm{O}$, Transition Met. Chem., 17, 364-368 (1992).

[112] P. Pérez-Lourido, J. Romero, J. A. García-Vázquez, A. Sousa, J. Zubieta, K. Maresca, Synthesis and characterisation of cobalt and nickel compounds with phosphinothiol ligands. Crystal and molecular structures of $\left.\left[\mathrm{Co}\left\{2-\left(\mathrm{Ph}_{2} \mathrm{P}\right)-6-\left(\mathrm{Me}_{3} \mathrm{Si}\right) \mathrm{C}_{6} \mathrm{H}_{3} \mathrm{~S}\right)\right\}_{3}\right]$, $\left.\left[\mathrm{Ni}\left\{2-\left(\mathrm{Ph}_{2} \mathrm{P}\right)-6-\left(\mathrm{Me}_{3} \mathrm{Si}\right) \mathrm{C}_{6} \mathrm{H}_{3} \mathrm{~S}\right)\right\}_{2}\right]$ and $\left[\mathrm{Co}\left\{{ }_{2}-\right.\right.$ ( $\left.\left.\mathrm{Ph}_{2} \mathrm{PO}\right)-6-\left(\mathrm{Me}_{3} \mathrm{Si}_{2} \mathrm{C}_{6} \mathrm{H}_{3} \mathrm{~S}\right\}_{2}\right]$, Polyhedron, 17, $4457-$ 4464 (1998).

[113] H. Sun, L. She, S. Fang, X. Li, Reaction of acyl(hydrido)cobalt(III) complexes with (2-diphenylphosphanyl)thiophenol and the influence of chelating ligands containing hard/soft donor atoms on the stability of cobalt complexes, Polyhedron, 27, 854-860 (2008).

[114] A. Hildebrand, M. B. Sárosi, P. Lönnecke, L. SilaghiDumitrescu, E. Hey-Hawkins, Unsymmetrical dinuclear rhodium complexes with arsanyl- and phosphanylarylthiolato ligands $\left[\mathrm{Rh}\left(\mu-\mathrm{S}-2-\mathrm{EPh}_{2} \mathrm{C}_{6} \mathrm{H}_{4}-\right.\right.$ $\left.\left.\kappa^{2} S, E\right)_{2} \mathrm{Rh}(\mathrm{cod})\right](\mathrm{E}=\mathrm{As}, \mathrm{P})$, Rev. Roum. Chim., 55, 885-896 (2010).

[115] J. R. Dilworth, J. R. Miller, N. Wheatley, M. J. Baker, J. G. Sunley, Novel catalysts for the carbonylation of methanol, J. Chem. Soc., Chem. Commun., 1579 1581 (1995).

[116] M. J. Baker, J. R. Dilworth, J. G. Sunley, N. Wheatley, Process for the carbonylation of methanol or a reactive derivative thereof, Patent: EP632006A1, (1995).

[117] L. Dahlenburg, K. Herbst, M. Kühnlein, Koordinationschemie funktioneller phosphane. III. rhodiumund iridiumkomplexe mit 2-(diphenylphosphanyl) phenolato- und 2-(diphenylphosphanyl)thiophenolato-liganden, Z. Anorg. Allg. Chem., 623, 250-258 (1997).

[118] J. R. Dilworth, C. Lu, J. R. Miller, Y. Zheng, Complexes of 2-diphenylphosphinobenzenethiol and 2-diphenyl phosphino-6-trimethylsilylbenzenethiol with rhodium and iridium. crystal and molecular structures of $\left[\mathrm{IrCI}_{2}\left(\mathrm{Ph}_{2} \mathrm{PC}_{6} \mathrm{H}_{4} \mathrm{~S}\right)\left(\mathrm{PMePh}_{2}\right)_{2}\right]$ and $\left[\mathrm{Ir}\left(\mathrm{Ph}_{2} \mathrm{PC}_{6} \mathrm{H}_{4} \mathrm{~S}\right)_{3}\right] \cdot 0.75 \mathrm{CH}_{2} \mathrm{Cl}_{2}, J$. Chem. Soc., Dalton Trans., 1957-1964 (1995).
[119] A. Benefiel, D. M. Roundhill, W. C. Fultz, A. L. Rheingold, A Menschutkin type amine alkylation involving methyl transfer to benzylamine from palladium(II) chelate complexes of o-(diphenylphosphino)thioanisole, Inorg. Chem., 23, 33163324 (1984).

[120] J. Real, E. Prat, A. Polo, Á. Álvarez-Larena, J. F. Piniella, Unexpected cis preference in palladium(II) bis (diphenylphosphinoarylthiolato) complexes. Crystal structure of cis- $\left[\mathrm{Pd}\left(\mathrm{PPh}_{2}\left(\mathrm{C}_{6} \mathrm{H}_{4}-2-\mathrm{S}\right)\right)_{2}\right]$, Inorg. Chem. Commun., 3, 221-223 (2000).

[121] D. Canseco-González, V. Gómez-Benítez, S. Hernández-Ortega, R.A. Toscano, D. Morales-Morales, Transmetallation reactions of $\left[\mathrm{Sn}(\mathrm{R})_{2}\left(\mathrm{Ph}_{2} \mathrm{PC}_{6} \mathrm{H}_{4}-\right.\right.$ 2-S $)_{2}$ ] with metal complexes of the Group 10: Stereoselective synthesis of cis- $\left[\mathrm{M}\left(\mathrm{Ph}_{2} \mathrm{PC}_{6} \mathrm{H}_{4}-2-\mathrm{S}\right)_{2}\right]$ $(\mathrm{M}=\mathrm{Ni}, \mathrm{Pd}, \mathrm{Pt})$, J. Organomet. Chem., 679, 101-109 (2003).

[122] J. Fierro-Arias, D. Morales-Morales, S. Hernandez-Ortega, cis-Bis[2-(diphenylphosphino)benzenethiolato- $\kappa^{2} \mathrm{P}, \mathrm{S}$ ]palladium(II), Acta Cryst. E, 64, m1196 (2008).

[123] A. Benefiel, D. M. Roundhill, Menschutkin type amine alkylations involving methyl transfer from platinum(II) chelate complexes of o(diphenylphosphino)thiophenetole, Inorg. Chem., 25, 4027-4031 (1986).

[124] J. R. Dilworth, A. J. Hutson, J. Zubieta, Q. Chen, The preparation and electrochemistry of gold(III), palladium(II) and platinum(II) complexes with 2-(diphenylphosphino)thiobenzene: X-ray crystal structure of $\left[\mathrm{Au}\left(\mathrm{Ph}_{2} \mathrm{PC}_{6} \mathrm{H}_{4} \mathrm{~S}\right)\left(\mathrm{Ph}_{2}\right]\left[\mathrm{BPh}_{4}\right]\right.$, Transition Met. Chem., 19, 61-64 (1994).

[125] J. S. Kim, J. H. Reibenspies, M. Y. Darensbourg, Characteristics of nickel(0), nickel(I), and nickel(II) in phosphino thioether complexes: molecular structure and S-dealkylation of $\left(\mathrm{Ph}_{2} \mathrm{P}\left(\mathrm{o}-\mathrm{C}_{6} \mathrm{H}_{4}\right) \mathrm{SCH}_{3}\right)_{2} \mathrm{Ni}^{0}$, J. Am. Chem. Soc., 118, 4115-4123 (1996).

[126] E. Block, G. Ofori-Okai, H. Kang, J. Zubieta, Complexes of $\mathrm{Ni}(\mathrm{II})$ with sterically-hindered thiolate ligands. Crystal structures of complexes with the $\left[\mathrm{NiS}_{2} \mathrm{~N}_{2}\right]$, $\left[\mathrm{NiS}_{2} \mathrm{P}_{2}\right]$ and $\left[\mathrm{NiS}_{2} \mathrm{O}_{2}\right]$ cores, Inorg. Chim. Acta, 188, 7-13 (1991).

[127] A. Hildebrand, I. Sarosi, P. Lönnecke, L. SilaghiDumitrescu, M.B. Sarosi, I. Silaghi-Dumitrescu, E. Hey-Hawkins, Heteropolytopic phosphanylarylthiolato ligands: formation of cis isomers of nickel(II), palladium(II) and platinum(II) complexes with 1-P(Biph)-2-SHC ${ }_{6} \mathrm{H}_{4}$ (Biph = 1,1'-biphenyl-2,2'diyl), Dalton Trans., 41, 7729-7736 (2012). 
[128] E. C. Constable, C. E. Housecroft, P. Kopecky, E. Schonhofer, J. A. Zampese, Restricting the geometrical relaxation in four-coordinate copper(I) complexes using face-to-face and edge-to-face $\pi$-interactions, CrystEngComm, 13, 2742-2752 (2011).

[129] P. Perez-Lourido, J. A. Garcia-Vazquez, J. Romero, P. Fernandez, A. Sousa-Pedrares, A. Sousa, Bis[2(diphenylphosphinoyl)benzene] disulfide, Acta Cryst. C, 56, e101-e102 (2000).

[130] P. Perez-Lourido, J. A. Garcia-Vazquez, J. Romero, A. Sousa, E. Block, K. P. Maresca, J. Zubieta, Synthesis and structural characterization of neutral silver(I) complexes with arenephosphinothiols. crystal structures of $\left[\mathrm{Ag}_{4}\left\{2-\left(\mathrm{Ph}_{2} \mathrm{P}\right)-6-\left(\mathrm{Me}_{3} \mathrm{Si}\right) \mathrm{C}_{6} \mathrm{H}_{6} \mathrm{~S}\right\}_{4}\right]$ and $\left[\mathrm{Ag}_{4}\left\{2-\left(\mathrm{Ph}_{2} \mathrm{PO}\right)-6-\left(\mathrm{Me}_{3} \mathrm{Si}\right) \mathrm{C}_{6} \mathrm{H}_{3} \mathrm{~S}\right\}_{4}\right]$, Inorg. Chem., 38, 538-544 (1999).

[131] P. G. Jones, R. Terroba, E. Fernandez, M. Laguna, Tris(pentafluorophenyl)[2-(diphenylphosphino) thiophenol-kP]gold(III) dichloromethane solvate, Acta Cryst. E, 58, m90-m92 (2002).

[132] P. Perez-Lourido, J. Romero, J. A. Garcia-Vazquez, A. Sousa, K. P. Maresca, J. Zubieta, Synthesis and characterization of zinc and cadmium compounds with arenephosphinothiol ligands. crystal and molecular structures of $\left[\mathrm{Cd}_{2}\left\{2-\left(\mathrm{Ph}_{2} \mathrm{PO}\right)\right.\right.$ $\left.\left.\mathrm{C}_{6} \mathrm{H}_{4} \mathrm{~S}\right\}_{4}\right], \quad\left[\mathrm{Zn}\left\{2-\left(\mathrm{Ph}_{2} \mathrm{P}\right)-6-\left(\mathrm{Me}_{3} \mathrm{Si}\right) \mathrm{C}_{6} \mathrm{H}_{3} \mathrm{~S}\right\}_{2}\right], \quad[\mathrm{Cd}-$ $\left.\left\{2-\left(\mathrm{Ph}_{2} \mathrm{PO}\right)-6-\left(\mathrm{Me}_{3} \mathrm{Si}\right) \mathrm{C}_{6} \mathrm{H}_{3} \mathrm{~S}\right\}_{2}\left(\mathrm{CH}_{3} \mathrm{OH}\right)\right]$, and $[\mathrm{Zn}-$ $\left\{\mathrm{PhPO}\left(\mathrm{C}_{6} \mathrm{H}_{4} \mathrm{~S}-2\right)_{2}\right\}$ (bipy) $]$, Inorg. Chem., 38, 37093715 (1999).

[133] P. Fernández, A. Sousa-Pedrares, J. Romero, J.A. García-Vázquez, A. Sousa, P. Pérez-Lourido, Zinc(II), cadmium(II), mercury(II), and ethylmercury(II) complexes of phosphinothiol ligands, Inorg. Chem., 47, 2121-2132 (2008).

[134] P. Barbaro, F. Cecconi, C. A. Ghilardi, S. Midollini, A. Orlandini, A. Vacca, Metal coordination and Hg-C bond protonolysis in organomercury(II) compounds. Synthesis, characterization, and reactivity of the tetrahedral complexes $\left[\left(\mathrm{np}_{3}\right) \mathrm{HgR}\right]\left[\left(\mathrm{CF}_{3}\right) \mathrm{SO}_{3}\right]$ $\left\{\mathrm{np}_{3}=\mathrm{N}\left(\mathrm{CH}_{2} \mathrm{CH}_{2} \mathrm{PPh}_{2}\right)_{3} ; \mathrm{R}=\mathrm{CH}_{3}, \mathrm{C}_{2} \mathrm{H}_{5}, \mathrm{C}_{6} \mathrm{H}_{5}\right\}$, Inorg. Chem., 33, 6163-6170 (1994).

[135] A. Garoufis, S. P. Perlepes, A. Schreiber, R. Bau, N. Hadjiliadis, Mercury(II)-carbon bond cleavage due to the coordination of the metal by $2-\left(2^{\prime}-\right.$ pyridyl $)$ quinoxaline $(\mathrm{L})$ : preparation and characterization of $\left[\mathrm{Hg}_{2} \mathrm{I}_{4} \mathrm{~L}_{2}\right]$ derived from the reaction of $\mathrm{CH}_{3} \mathrm{HgI}$ and L, Polyhedron, 15, 177-182 (1996).
[136] J. S. Casas, M.S. García-Tasende, A. Sánchez, J. Sordo, E.M. Vázquez-López, Protodemetallation of pyridinephenylmercury(II) compounds by diphenyldithiophosphinic acid. The molecular and crystal structure of $\left[\mathrm{Hg}_{2}\left(\mathrm{~S}_{2} \mathrm{PPh}_{2}\right)_{4}\right]$, Inorg. Chim. Acta, 256, 211-216 (1997).

[137] M. Wilhelm, S. Deeken, E. Berssen, W. Saak, A. Lützen, R. Koch, H. Strasdeit, The first structurally authenticated organomercury $(1+)$ thioether complexes - mercury-carbon bond activation related to the mechanism of the bacterial enzyme organomercurial lyase, Eur. J. Inorg. Chem., 2004, 2301-2312 (2004).

[138] P. Perez-Lourido, J. Romero, J. A. Garcia-Vazquez, A. Sousa, K. Maresca, J. Zubieta, Synthesis and characterization of indium compounds with phosphinothiol ligands. The crystal and molecular structures of $\left[\operatorname{In}\left\{2-\left(\mathrm{Ph}_{2} \mathrm{P}\right) \mathrm{C}_{6} \mathrm{H}_{4} \mathrm{~S}\right\}_{3}\right], \quad\left[\operatorname{In}\left\{2-\left(\mathrm{Ph}_{2} \mathrm{P}\right)-6-\left(\mathrm{Me}_{3} \mathrm{Si}\right)\right.\right.$ $\left.\left.\mathrm{C}_{6} \mathrm{H}_{3} \mathrm{~S}\right\}_{2}\left\{2-\left(\mathrm{Ph}_{2} \mathrm{PO}\right)-6-\left(\mathrm{Me}_{3} \mathrm{Si}\right) \mathrm{C}_{6} \mathrm{H}_{3} \mathrm{~S}\right\}\right]$, and $\left[\mathrm{NMe}_{4}\right]$ $\left[\mathrm{In}\left\{\mathrm{PhP}\left(\mathrm{C}_{6} \mathrm{H}_{4} \mathrm{~S}-2\right)_{2}\right\}_{2}\right] \cdot \mathrm{CH}_{3} \mathrm{CN}$, Inorg. Chem., 38, 1293-1298 (1999).

[139] P. Pérez-Lourido, J. Romero, J. A. García-Vázquez, A. Sousa, J. Zubieta, U. Russo, Diorganotin(IV) derivatives of arenephosphinothiol ligands. The crystal structure of $\left[\mathrm{Ph}_{2} \mathrm{Sn}\left\{2-\left(\mathrm{Ph}_{2} \mathrm{P}\right) \mathrm{C}_{6} \mathrm{H}_{4} \mathrm{~S}\right\}_{2}\right]$ and $\left[\mathrm{Me}_{2} \mathrm{Sn}\left\{2-\left(\mathrm{Ph}_{2} \mathrm{PO}\right)-6-\left(\mathrm{Me}_{3} \mathrm{Si}\right) \mathrm{C}_{6} \mathrm{H}_{3} \mathrm{~S}\right\}_{2}\right], \quad J$. Organomet. Chem., 595, 59-65 (2000).

[140] E. J. Fernández, M. B. Hursthouse, M. Laguna, R. Terroba, Phosphinethiolate tin(IV)-11 group-metal derivatives. X-ray structure of $\left[\mathrm{Au}_{2} \mathrm{Sn}(t \mathrm{Bu})_{2}\left(\mathrm{C}_{6} \mathrm{~F}_{5}\right)_{2}\right.$ $\left.\left(\mathrm{SC}_{6} \mathrm{H}_{4} \mathrm{PPh}_{2}\right)_{2}\right]$, J. Organomet. Chem., 574, 207-212 (1999).

[141] P. Pérez-Lourido, L. Valencia, J. Romero, J. A. García-Vázquez, A. Sousa, J. Zubieta, Bismuth(III) complexes derivatives of phosphinothiol ligands: The crystal structure of $\left[\mathrm{Bi}\left\{2-\left(\mathrm{Ph}_{2} \mathrm{P}\right) \mathrm{C}_{6} \mathrm{H}_{4} \mathrm{~S}\right\}_{3}\right]$, Polyhedron, 45, 200-203 (2012).

[142] I. Sárosi, A. Hildebrand, P. Lönnecke, L. SilaghiDumitrescu, E. Hey-Hawkins, Reaction of a heterotopic P,SAs ligand with group 10 metal(II) complexes: As-S bond cleavage and the formation of two unusual trinuclear structural isomers for $\mathrm{Pd}$ and $\mathrm{Pt}$, Dalton Trans., 41, 5326-5333 (2012).

[143] I. Sárosi, M.B. Sárosi, E. Hey-Hawkins, L. SilaghiDumitrescu, Reaction of a heterotopic P,SAs ligand with group 10 metal(II) complexes: a theoretical study, Studia UBB Chemia, LVII, 139-146 (2012). 
